\title{
Evaluation of chemical transport model predictions of primary organic aerosol for air masses classified by particle component-based factor analysis
}

\author{
C. A. Stroud ${ }^{1}$, M. D. Moran ${ }^{1}$, P. A. Makar ${ }^{1}$, S. Gong ${ }^{1}$, W. Gong ${ }^{1}$, J. Zhang ${ }^{1}$, J. G. Slowik ${ }^{4}$, J. P. D. Abbatt ${ }^{4}$, G. Lu ${ }^{1}$, \\ J. R. Brook ${ }^{1}$, C. Mihele ${ }^{1}$, Q. Li ${ }^{2}$, D. Sills ${ }^{3}$, K. B. Strawbridge ${ }^{1}$, M. L. McGuire ${ }^{4}$, and G. J. Evans ${ }^{4}$ \\ ${ }^{1}$ Air Quality Research, Environment Canada, 4905 Dufferin Street, Toronto, ON, M3H 5T4, Canada \\ ${ }^{2}$ Meteorological Service of Canada - Ontario Operations, Environment Canada, 4905 Dufferin Street, Toronto, ON, M3H \\ 5T4, Canada \\ ${ }^{3}$ Cloud Physics and Severe Weather Research Environment Canada 4905 Dufferin Street Toronto, ON, Canada, \\ M3H 5T4, Canada \\ ${ }^{4}$ Department of Chemistry University of Toronto 80 St. George St. Toronto, ON, Canada,, M5S 3H6, Canada
}

Correspondence to: C. A. Stroud (craigstroud@ec.gc.ca)

Received: 19 December 2011 - Published in Atmos. Chem. Phys. Discuss.: 24 February 2012

Revised: 23 July 2012 - Accepted: 31 August 2012 - Published: 17 September 2012

\begin{abstract}
Observations from the 2007 Border Air Quality and Meteorology Study (BAQS-Met 2007) in Southern Ontario, Canada, were used to evaluate predictions of primary organic aerosol (POA) and two other carbonaceous species, black carbon $(\mathrm{BC})$ and carbon monoxide $(\mathrm{CO})$, made for this summertime period by Environment Canada's AURAMS regional chemical transport model. Particle component-based factor analysis was applied to aerosol mass spectrometer measurements made at one urban site (Windsor, ON) and two rural sites (Harrow and Bear Creek, ON) to derive hydrocarbon-like organic aerosol (HOA) factors. A novel diagnostic model evaluation was performed by investigating model POA bias as a function of HOA mass concentration and indicator ratios (e.g. BC/HOA). Eight case studies were selected based on factor analysis and back trajectories to help classify model bias for certain POA source types. By considering model POA bias in relation to co-located $\mathrm{BC}$ and $\mathrm{CO}$ biases, a plausible story is developed that explains the model biases for all three species.

At the rural sites, daytime mean $\mathrm{PM}_{1}$ POA mass concentrations were under-predicted compared to observed HOA concentrations. POA under-predictions were accentuated when the transport arriving at the rural sites was from the Detroit/Windsor urban complex and for short-term periods of biomass burning influence. Interestingly, the daytime $\mathrm{CO}$
\end{abstract}

concentrations were only slightly under-predicted at both rural sites, whereas $\mathrm{CO}$ was over-predicted at the urban Windsor site with a normalized mean bias of $134 \%$, while good agreement was observed at Windsor for the comparison of daytime $\mathrm{PM}_{1}$ POA and HOA mean values, $1.1 \mu \mathrm{g} \mathrm{m}^{-3}$ and $1.2 \mu \mathrm{g} \mathrm{m}^{-3}$, respectively. Biases in model POA predictions also trended from positive to negative with increasing HOA values. Periods of POA over-prediction were most evident at the urban site on calm nights due to an overly-stable model surface layer. This model behaviour can be explained by a combination of model under-estimation of vertical mixing at the urban location, under-representation of PM emissions for on-road traffic exhaust along major urban roads and highways, and a more structured allocation of area POA sources such as food cooking and dust emissions to urban locations. A downward trend in POA bias was also observed at the urban site as a function of the $\mathrm{BC} / \mathrm{HOA}$ indicator ratio, suggesting a possible association of POA under-prediction with under-representation of diesel combustion sources. An investigation of the emission inventories for the province of Ontario and the nearby US state of Indiana also suggested that the top POA area emission sources (food cooking, organicbound to dust, waste disposal burning) dominated over mobile and point sources, again consistent with a mobile underestimation. 
We conclude that more effort should be placed at reducing uncertainties in the treatment of several large POA emission sources, in particular food cooking, fugitive dust, waste disposal burning, and on-road traffic sources, and especially their spatial surrogates and temporal profiles. This includes using higher spatial resolution model grids to better resolve the urban road network and urban food cooking locations. We also recommend that additional sources of urbanscale vertical mixing in the model, such as a stronger urban heat island effect and vehicle-induced turbulence, would help model predictions at urban locations, especially at night time.

\section{Introduction}

Particulate matter (PM) has important health impacts on cardiovascular morbidity and lung function (Pope and Dockery, 2006; Mauderly and Chow, 2008). Even trace levels of some directly-emitted aerosol chemical components (e.g., PAHs) can be quite toxic and have significant adverse human health effects (Boström et al., 2002). PM emissions are also essential in determining cloud-condensation-nuclei number concentration, which impacts cloud radiative forcing properties and regional-scale climates (Zhang, 2008; Grell et al., 2011). However, it is challenging to establish a cause-and-effect relationship with specific sources contributing to PM because of the wide array of particle sources and atmospheric transformation mechanisms. To simulate the complex processing of primary PM emissions in the Earth system, air quality (AQ) and climate modeling systems are being developed as predictive tools (e.g., IPCC AR4 WG1, 2007; Kelly et al., 2011) and for providing policy guidance for emission reduction strategies via retrospective simulations (e.g., Environment Canada and Health Canada, 2011).

The carbonaceous component of PM is the most complex component to characterize due to the wide range of constituent organic compounds with different sources and varying chemical reactivity and physical properties such as volatility, light scattering, light absorption, and hygroscopicity. Organic aerosol (OA) and black carbon (BC) are both key PM chemical components that are co-emitted from combustion sources. An organic carbon coating on BC particles can alter their morphology (Chan et al., 2010) by enhancing the collapse of BC clusters, which can in turn alter the scattering and absorption properties of the emitted particles (Andreae and Gelencsér, 2006). The organic component of combustion aerosol is relatively hydrophobic, typically, $>85 \%$ by mass (Schauer et al., 1999; Sage et al., 2008). In experimental dilution samplers, the organic component of combustion aerosol has been shown to obey absorptive partitioning theory (e.g., Robinson et al., 2010), which suggests that it is dynamic in nature and can evaporate on dilution to atmospheric scales.

Primary organic aerosol (POA) is defined as directly emitted organic aerosol (e.g. traffic emissions, biomass burning).
POA has received less attention in the literature than secondary organic aerosol (SOA). However, POA is important because it can act as a seed for organic vapour condensation and it is believed to contain some toxic materials (e.g., dioxins: Lohmann and Jones, 1998; Lee et al., 2007). Traditionally, POA has been thought of as an inert tracer in AQ models; however, recent laboratory studies have raised some doubts about this assumption (Robinson et al., 2010). For the above reasons, it is important to try to isolate POA from SOA in model evaluation studies.

OA data acquired by the Aerosol Mass Spectrometer (AMS) instrument have been deconvolved into hydrocarbonlike OA (HOA) and oxygenated OA (OOA) components (Zhang et al., 2005). HOA has been linked to primary emissions such as liquid fuel combustion. Zhang et al. (2007) performed factor analysis on AMS data from 37 field campaigns and found that HOA represented $36 \%$ and $17 \%$ of OA at urban and suburban sites, respectively. There has been discussion in the literature about whether HOA includes other sources such as food cooking and biomass burning. A positive matrix factorization (PMF) analysis of AMS data in Zurich, Switzerland during the summer (Lanz et al., 2007) ascribed a $10 \%$ contribution from liquid fuel combustion and a $10-15 \%$ contribution from local food cooking to OA in which both sources loaded onto the HOA factor with a 2-component solution (HOA, OOA) but were separated with a 3-component solution (HOA, food cooking, OOA). Mohr et al. (2009) analyzed the unit resolution AMS spectra from meat cooking, plastic burning, paper burning, and wood burning and concluded that meat cooking and plastic burning grouped with the HOA factor, whereas paper burning and wood burning grouped on a unique factor (termed BBOA). In general, with the unit resolution AMS and a limited number of PMF factors chosen, biomass burning will load on its own factor for air masses sampled near biomass burning sources but will load mostly onto the HOA factor for a smaller regional biomass burning influence (Slowik et al., 2011).

POA is challenging to model because its emissions have large uncertainties in terms of source activity levels (e.g., vehicle distance traveled), fuel-based PM emission factors (e.g., mass of PM emitted per distance traveled), PM chemical and size profiles (e.g., POA fraction of PM, $\mathrm{PM}_{1}$ fraction of $\mathrm{PM}_{2.5}$ ), source spatial and temporal profiles, as well as organic-component volatility distribution (Robinson et al., 2010). Nonetheless, source-oriented AQ modeling systems have advanced in terms of predicting POA and SOA ambient concentrations and in estimating biogenic and anthropogenic contributions to SOA formation. Good agreement between source-resolved models and receptor-based analysis can also increase our confidence in the source apportionment of POA. Ying et al. (2007) used the CIT/UCD model to evaluate Los Angeles $\mathrm{PM}_{2.5}$ data. $\mathrm{BC}$ and OA concentrations were underpredicted at rush-hour periods, which were attributed to a bias in the diesel emission inventory. Bhave 
et al. (2007) performed a diagnostic evaluation of CMAQmodel-predicted $\mathrm{PM}_{2.5}$ OA using molecular marker measurements from eight sites in the Southeastern US during the summer. Results indicate that the modelled contributions from vehicle exhaust and biomass combustion were unbiased across the region for most sites; however, in Atlanta, overestimation of vehicle emissions was significant but was partially compensated by underestimates of other sources. Lane et al. (2007) evaluated the PMCAMx model against chemicalmass-balance results from sites in the eastern US. There was evidence that POA concentrations from natural gas, wood burning, and off-road diesel combustion were overestimated. Zhang and Ying (2010) used the UCD/CIT model to study the source contributions to $\mathrm{PM}_{2.5}$ in the Houston-Galveston, Texas area. $\mathrm{PM}_{2.5} \mathrm{BC}$ in the 4-km model domain was largely from diesel combustion while POA was largely from a combination of gasoline and diesel combustion and industrial sources. Predicted POA from diesel and gasoline combustion agreed well with observed HOA, but predicted POA from biomass burning under-represented the biomass burning organic factor (BBOA) and differences were attributed to wildfire emissions missing from the inventory.

The Border Air Quality and Meteorology Study (BAQSMet 2007) collected state-of-the-art, high-time-resolution OA measurements at two rural sites and one urban site in southwestern Ontario in summer 2007 (Brook et al., 2012). Southwestern Ontario is home to some of the highest PM concentration levels in Canada. Southwestern Ontario is also one of the most challenging regions for AQ predictions due to the presence of both a wide range of sources and complex mesoscale meteorology associated with the southern Great Lakes of North America.

This study presents a detailed evaluation on the current state of chemical transport model (CTM) predictions of primary organic aerosol (POA) using Environment Canada's AURAMS model, (Makar et al., 2010a; Stroud et al., 2011), recent Canadian and US national emissions inventories, and detailed field measurements from the BAQS-Met field study. The objectives of this study are to quantify POA biases that can be expected with AURAMS and to identify where the greatest uncertainties reside so as to guide future model improvements. The novel approach that is followed is to analyze model biases for POA in terms of pollutant concentrations and indicators of air-mass sources and history (e.g., HOA concentration, ratios of BC/HOA). Case study periods selected using single-particle PMF analysis (McGuire et al., 2011) and meteorological back trajectories provide additional information to aid in diagnosing systematic model biases by source type.

The paper is organized as follows. Section 2 describes the scientific methods that were used; Sect. 3 presents results on: (3.1) POA sources affecting the study area, (3.2) campaign statistics for POA at the Windsor urban site, (3.3) a correlation plot for POA bias as a function of POA and indicator ratios for Windsor, (3.4) campaign statistics for $\mathrm{CO}$ and $\mathrm{BC}$ at
Windsor, (3.5) campaign statistics for POA at the rural sites, (3.6) campaign statistics for $\mathrm{CO}$ and $\mathrm{BC}$ at the rural sites, and (3.7) case studies at rural sites; Sect. 4 presents discussion on: (4.1) other receptor-modelling results in comparison to our results and (4.2) recommendations for future work. Lastly, Sect. 5 provides conclusions and a Supplementary Information section provides supporting material and additional analyses.

\section{Methodology}

\subsection{BAQS-Met field study and supersites}

The BAQS-Met field campaign was conducted from 20 June to 10 July 2007 in southwestern Ontario east of the Detroit, Michigan-Windsor, Ontario urban area and close to the international border between Canada and the US The DetroitWindsor urban area is also a major industrial area with automobile manufacturing, steel production, chemical production, electric power generation and petrochemical refining sectors. The BAQS-Met study area is also influenced by major point emission sources located along the St. Clair River to the north of Detroit (petrochemical refineries and electricpower generating stations), other cities such as Toledo and Cleveland, and electric-power generating stations located on the southern shores of Lake Erie (see Fig. 1).

The study area is also frequently impacted by long-range transport of pollution from the Ohio Valley and US Midwest into Southern Ontario. In addition to such synopticscale flows, complex mesoscale circulations frequently occur in the BAQS-Met study area in the summer due to the presence of two of eastern North America's five Great Lakes, Lakes Erie and Huron, and another large lake, Lake St. Clair, which is located just northeast of Detroit-Windsor. These terrain-forced mesoscale circulations, including multiple lake breezes and land breezes, can have a strong influence on pollutant transport and transformation, including the pollutants carried in the urban plume from Detroit-Windsor (Sills et al., 2011).

Four AQ super-sites were operated during the study; their locations are shown in Fig. 1. The Windsor site was located in the eastern half of that city just south of a major highway carrying cross-border traffic to the Ambassador Bridge joining Canada and the US The Bear Creek site was located $\sim 60 \mathrm{~km}$ east-northeast of Detroit-Windsor across Lake St. Clair in a wetland area surrounded by farmland. The Harrow site was situated $\sim 40 \mathrm{~km}$ southeast of Detroit-Windsor and $\sim 5 \mathrm{~km}$ north of Lake Erie on farmland. The Ridgetown site was the eastern-most site and was also located on farmland just north of the Lake Erie shoreline. This site geometry allowed both the Detroit-Windsor urban plume and regional air masses to be sampled simultaneously at the rural sites on many days. The high-time-resolution $\mathrm{PM}_{1} \mathrm{OA}$ data considered in this study were collected by AMS instruments at three 


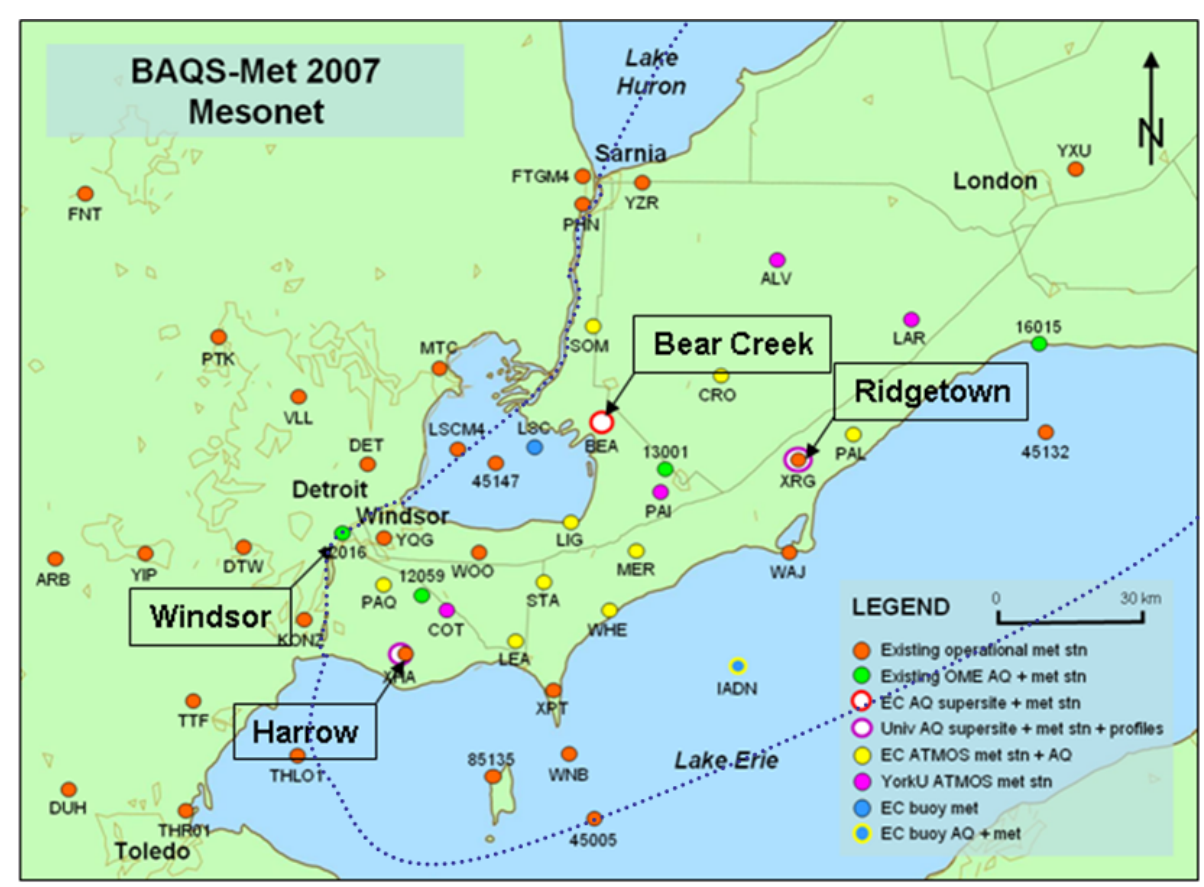

Fig. 1. Locations for the four atmospheric chemistry measurement super-sites (labeled in boxes) in southwestern Ontario, Canada during the BAQS-Met field campaign. Locations of existing and enhanced meteorological stations are also marked. Dotted line represents the US-Canada border.

of these sites: Windsor, Harrow, and Bear Creek. BC and CO measurements were also made at Windsor, Harrow, and Bear Creek.

More information about BAQS-Met may be found in Brook et al. (2012); Hayden et al. (2011); Levy et al. (2010); Makar et al. (2010a,b); Sills et al. (2011); Slowik et al. (2011), and Stroud et al. (2011).

\subsection{AQ modelling system description and setup}

AURAMS is a regional AQ modelling system developed by Environment Canada (EC); the acronym AURAMS stands for "A Unified Regional Air-quality Modelling System". AURAMS consists of three main components: a numerical weather prediction model; an off-line regional chemical transport model (CTM); and an emissions processing system. Version 1.4.0 of the AURAMS CTM, which was used in this study, was driven by version 3.2.2 of the Canadian operational weather forecast model, GEM (Global Environmental Multiscale model) (Côté et al., 1998) and emissions files prepared using version 2.3 of the SMOKE emissions processing system (CEP, 2011). Note that we reference specific version numbers here so that the model development and evaluation over time can be documented and accessed by the modeling community.

The GEM meteorological model with physics version 4.5 was run from 1 June to 31 August 2007 for a $575 \times 641$ global, variable-resolution, rotated latitude-longitude horizontal grid with a $432 \times 565$ uniform subgrid with $0.1375^{\circ}$
( $\sim 15.3-\mathrm{km})$ grid spacing centered on and covering North America. 58 hybrid vertical coordinate levels from the Earth's surface to $10 \mathrm{hPa}$ were employed, with layer thickness increasing monotonically with height, and a 450-s time step was used. A high-resolution limited-area configuration of GEM was also run for part of this period (17 June to 11 July) for a domain covering the Great Lakes area: $565 \times 494 \times 58$ grid, $0.0225^{\circ}(\sim 2.5-\mathrm{km})$ horizontal grid spacing, and 60-s time step. Hourly output from the global GEM simulation was used to provide boundary conditions for the high-resolution limited-area GEM simulations. More details may be found in Makar et al. (2011a).

Wind fields from the high-resolution GEM simulations were also used to produce 48-h, three-dimensional, kinematic back trajectories arriving at the BAQS-Met study super-sites (see accompanying Supplemental Information section). The back trajectories were calculated using a 120$\mathrm{s}$ time step and five different arrival heights $(0.05,0.1,0.3$, 1 , and $3 \mathrm{~km}$ ) so the vertical directional shear could be estimated. The model takes into account advection by 3-D winds (Runge-Kutta temporal scheme of order 4). This trajectory model was originally developed by the Environmental Emergency Response team at EC's Canadian Meteorological Centre.

The AURAMS CTM includes representations of gas-, aqueous-, and particle-phase chemistry and predicts tropospheric ozone, size-distributed particulate matter (based on a sectional treatment), and acid deposition. Overall, the model 


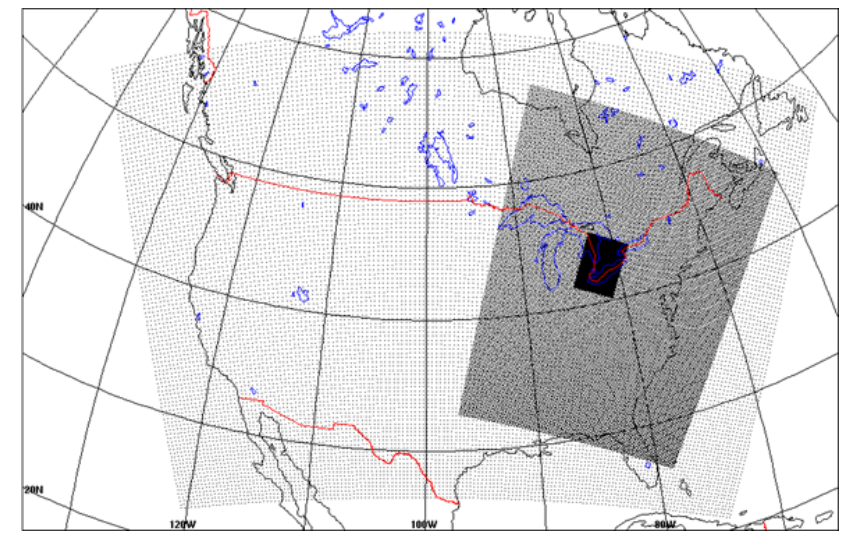

Fig. 2. AURAMS nested grid configuration for BAQS-Met simulations. Outermost grid has a horizontal grid spacing of $42 \mathrm{~km}$. Inner grids have horizontal grid spacings of 15 and $2.5 \mathrm{~km}$, respectively.

tracks 157 species: 49 gaseous species and nine aerosol species distributed over 12 logarithmically-distributed size bins ranging from 0.01 to $41 \mu \mathrm{m}$ in Stokes diameter. In this study, $\mathrm{PM}_{1}$ refers to particles with a Stokes diameter less than $0.68 \mu \mathrm{m}$ (mass in bins $1-6$ and 0.042 of bin 7). This corresponds to the vacuum aerodynamic diameter particle transmission cut-off of the AMS instrument (personal communication with Dr. John Liggio, assuming a particle density of $1.5 \mathrm{~g} \mathrm{~m}^{-3}$ and a shape factor of unity). The nine PM chemical species considered are POA, BC, SOA, sulphate, nitrate, ammonium, crustal material (CM), sea salt, and particlebound water. Removal processes include wet and dry deposition of both gases and particles. Operator splitting is applied to the various process parameterizations in the following order: point source emissions and plume rise; advection; vertical diffusion, gas-phase dry deposition, and surface emissions; gas-phase chemistry; aerosol processes (nucleation, condensation/evaporation, coagulation, sedimentation, dry deposition), in-cloud and below-cloud processes; and SOA formation. The most up-to-date descriptions of AURAMS process representations can be found in the following references: SOA formation in Slowik et al. (2010) and Stroud et al. (2011); gas-phase chemistry and speciation in Stroud et al. (2008); vertical mixing and urban-heat-island effects in Makar et al. (2006); cloud processing of pollutants in Gong et al. (2006); and aerosol particle dynamics in Gong et al. (2003). A three-level nested grid configuration was used for the AURAMS CTM, consisting of an outer continental grid with 42-km horizontal grid spacing, an inner eastern North American grid with $15-\mathrm{km}$ grid spacing, and a finescale $2.5-\mathrm{km}$ grid over the BAQS-Met study region (Fig. 2). Twenty-eight terrain-following modified-Gal-Chen vertical layers were used with monotonically-increasing spacing to $29 \mathrm{~km}$ a.g.l. starting from a 15 -m-thick lowest layer. The model time step was chosen proportionate to the grid spacing to maintain numerical stability. For this study, a 900-s time step was used for the $42-\mathrm{km}$ and $15-\mathrm{km}$ simulations while a 120 -s time step was used for the $2.5-\mathrm{km}$ simulation. Meteorological fields were provided for the $42-\mathrm{km}$ and $15-\mathrm{km}$ domains from the GEM 15-km simulations and for the 2.5$\mathrm{km}$ domain from the GEM $2.5-\mathrm{km}$ simulations. Chemical lateral boundary conditions (CLBC) derived from climatology are assumed for the 42-km continental domain (Makar et al., 2010b). All results presented here are from the innermost, highest-resolution domain.

\subsubsection{Treatment of emissions}

Files of hourly, speciated, gridded anthropogenic emissions were prepared for the three AURAMS CTM grids based on the 2006 Canadian, 2005 US, and 1999 Mexican national emission inventories (NEIs) using version 2.3 of the SMOKE emissions processing system. Emissions were separated into four major emissions source streams: on-road mobile (ORM) sources; off-road mobile and area (ORAA) sources; minor-point sources; and major-point sources. ORM sources include exhaust emissions and evaporative emissions from cars, light- and heavy-duty trucks, buses, and motorcycles. ORAA emissions include engine emissions from construction, agricultural, commercial and residential activities, marine, rail, and air transport, coal, oil, wood, and natural gas combustion, oil sands and mining vehicle fleets, solvent use, and fugitive emissions. Point sources are larger sources that emit at least 100 tonnes (Canada) or 100 tons (US) per year of at least one of the following pollutants: $\mathrm{SO}_{2}, \mathrm{NO}_{\mathrm{x}}, \mathrm{CO}$, VOC, $\mathrm{NH}_{3}, \mathrm{PM}_{2.5}$, or $\mathrm{PM}_{10}$ ). Minor-point sources include chimneys and smokestacks with a stack height less than or equal to $30 \mathrm{~m}$, and major-point sources include facilities with stack heights greater than $30 \mathrm{~m}$ (e.g., electric power generation units, smelters, refineries).

To obtain emissions of POA for the four source streams from the bulk $\mathrm{PM}_{2.5}$ emissions in the inventories (unspeciated emissions of particles with aerodynamic diameter less than $2.5 \mu \mathrm{m}$ ), four source-stream-specific $\mathrm{PM}_{2.5}$ chemical speciation profiles were employed. The POA percentages of bulk $\mathrm{PM}_{2.5}$ emissions were $34 \%$ for ORM emissions, $26 \%$ for ORAA emissions, $16 \%$ for minor-point emissions and $16 \%$ for major-point emissions. These splitting percentages were derived using the 2001 US NEI and PM chemical speciation profiles from the EPA SPECIATE4.2 profile library (US EPA). The profiles were grouped into the four source streams and then each profile was mass-weighted (based on the summed emissions in the NEI that use each profile divided by the total PM in a particular source stream) to arrive at the representative averaged splitting factors for each source stream. The speciated PM emissions thus obtained must also be size-disaggregated into the 12 size bins used by the AURAMS CTM; a weighted average of measured PM size distributions for different source types was applied for each of the four source streams based on measured size distributions presented in Eldering and Cass (1996). For example, 
the $\mathrm{PM}_{1}$ size fraction of $\mathrm{PM}_{2.5}$ bulk emissions is $0.96,0.73$, and 0.99 for ORM, ORAA, and point sources, respectively.

The annual inventory data were also temporally disaggregated to hourly emissions by applying source-specific monthly, weekly, and diurnal profiles within SMOKE to each of the hundreds of Canadian, US, and Mexican source types. The Canadian NEI data set was spatially disaggregated based on 42 spatial surrogate fields that, in turn, were derived from 28 socioeconomic categories from the 2001 Canadian census (e.g., population density, roadways, etc.).

Our base-case simulation assumed that the POA emissions were non-evaporative. Robinson et al. (2007) published results highlighting the potential importance of POA evaporation as a diesel exhaust plume mixes in a laboratory dilution sampler. Recently, Robinson et al. (2010) suggested that for high-emitting sources, the bias due to absorptive partitioning may be as high as a factor of $\sim 4$ in mass concentration depending on the level of dilution in the atmosphere. The POA emission factors reported in Schauer et al. (1999) may also be biased high by a factor of $\sim 2$ due to filter sampling artifacts (see Fig. 6c in Robinson et al., 2010). Over urban source regions, the modelled POA mass concentration scales close to linearly with the emissions strengths (Samaali et al., 2011). Our $\mathrm{PM}_{1}$ POA comparison to HOA will provide further evidence to determine whether a POA evaporation hypothesis is supported in comparing our CTM predictions based on current NEI data with the ambient data.

\subsection{Measurement techniques}

OA measurements were made at three BAQS-Met supersites: Windsor, Harrow, and Bear Creek (see Fig. 1). The three OA measurement sites were strategically located to sample both within the Detroit-Windsor air shed and the Detroit/Windsor urban plume under common wind directions. In general, when synoptic patterns produced gradient wind flows from the southwest, Harrow received only regional background air, including the influence of the Ohio River Valley and US Midwest, whereas Bear Creek received regional background air with Detroit-Windsor emissions superimposed. Conversely, when gradient wind flows were from the northwest, Bear Creek received clean continental air from Northern Michigan and Central Canada, whereas Harrow received this background air plus Detroit-Windsor emissions. Time periods when Bear Creek and Harrow were measuring similar POA mass concentration likely reflect periods when concentrations are representative of a regional background for the study region. In practice, however, these patterns are complicated by local lake-related circulation patterns (Levy et al., 2010), so measurements need to be examined on a case-by-case basis to understand the local source-receptor relationships.

$\mathrm{PM}_{1} \mathrm{OA}, \mathrm{SO}_{4}$, and $\mathrm{NO}_{3}$ measurements were made at both Bear Creek and Harrow using Aerodyne time-of-flight aerosol mass spectrometers (AMS), as described in detail in Slowik et al. (2011). Briefly, particle composition was measured by a unit mass resolution instrument (C-ToFAMS) deployed at Harrow from 17 June to 10 July and a high-resolution instrument (HR-ToF-AMS) deployed at Bear Creek from 28 June to 10 July. The AMS provides quantitative size-resolved mass spectra of the $\mathrm{PM}_{1}$ non-refractory component. As described in Slowik et al. (2011), collection efficiencies for both instruments were estimated on site. The OA mass spectra from the two instruments were analyzed by positive matrix factorization. The PMF solution arrived at in Slowik et al. (2011) consisted of four factors, which were labelled HOA (hydrocarbon-like OA), OOA-1 and OOA-2 (oxygenated OA, types 1 and 2), and an Unknown Factor (UNKN). The UNKN factor was a major component of OA only at the end of the study, coinciding with a period of high isoprene, low aromatics, and a sulphate plume from the US Midwest.

An aerosol time-of-flight mass spectrometer (ATOFMS) was also deployed at Harrow, ON, to characterize the composition of single particles (McGuire et al., 2011). Individual particles were classified into particle types and PMF was applied to their temporal trends to separate them into factors.

$\mathrm{PM}_{1} \mathrm{OA}, \mathrm{SO}_{4}$, and $\mathrm{NO}_{3}$ sampling with a unit-resolution AMS was also undertaken on EC's mobile laboratory, CRUISER, which was stationed for the majority of the BAQS-Met campaign in Windsor, ON. PMF analysis was also performed on the CRUISER AMS $\mathrm{PM}_{1}$ data. In this case, both organic and inorganic $m / z$ fragments were included and 6- to10-factor solutions were obtained and compared to known source profiles. Given the commonality of HOA, this factor appeared in each solution and there was little difference in the profile of $m / z$ and mass explained for the 7- to 10-factor solutions. In the 6-factor solution a biomass (wood) burning factor and the HOA factor were combined, whereas increasing the solution to seven factors separated these two factors. The 8-factor solution for HOA was selected for comparison with the AURAMS results because this HOA factor had the strongest overall correlation $(R=0.2)$ with known source profiles related to vehicle exhaust and other published HOA factor solutions.

$\mathrm{PM}_{2.5} \mathrm{BC}$ measurements were made by the EC CRUISER mobile laboratory at Windsor with a single particle soot photometer (SP2). At Bear Creek, EC measured $\mathrm{PM}_{2.5}$ black carbon (BC) with a multi-angle absorption photometer (MAAP). At Harrow, the University of Toronto group measured $\mathrm{PM}_{2.5} \mathrm{BC}$ with a Sunset Laboratory filter-based thermo-optical instrument, and EC also measured $\mathrm{PM}_{2.5} \mathrm{BC}$ there with a photo-acoustic soot spectrometer (Droplet Measurement Technology). CO was measured at Windsor, Harrow and Bear Creek with an infrared spectrophotometer (Thermo Scientific TECO 48).

A scanning LIDAR instrument was deployed on the RASCAL mobile laboratory at Ridgetown. LIDAR is a remot sensing technique that provides high temporal and vertical information on atmospheric PM layers and was used to 

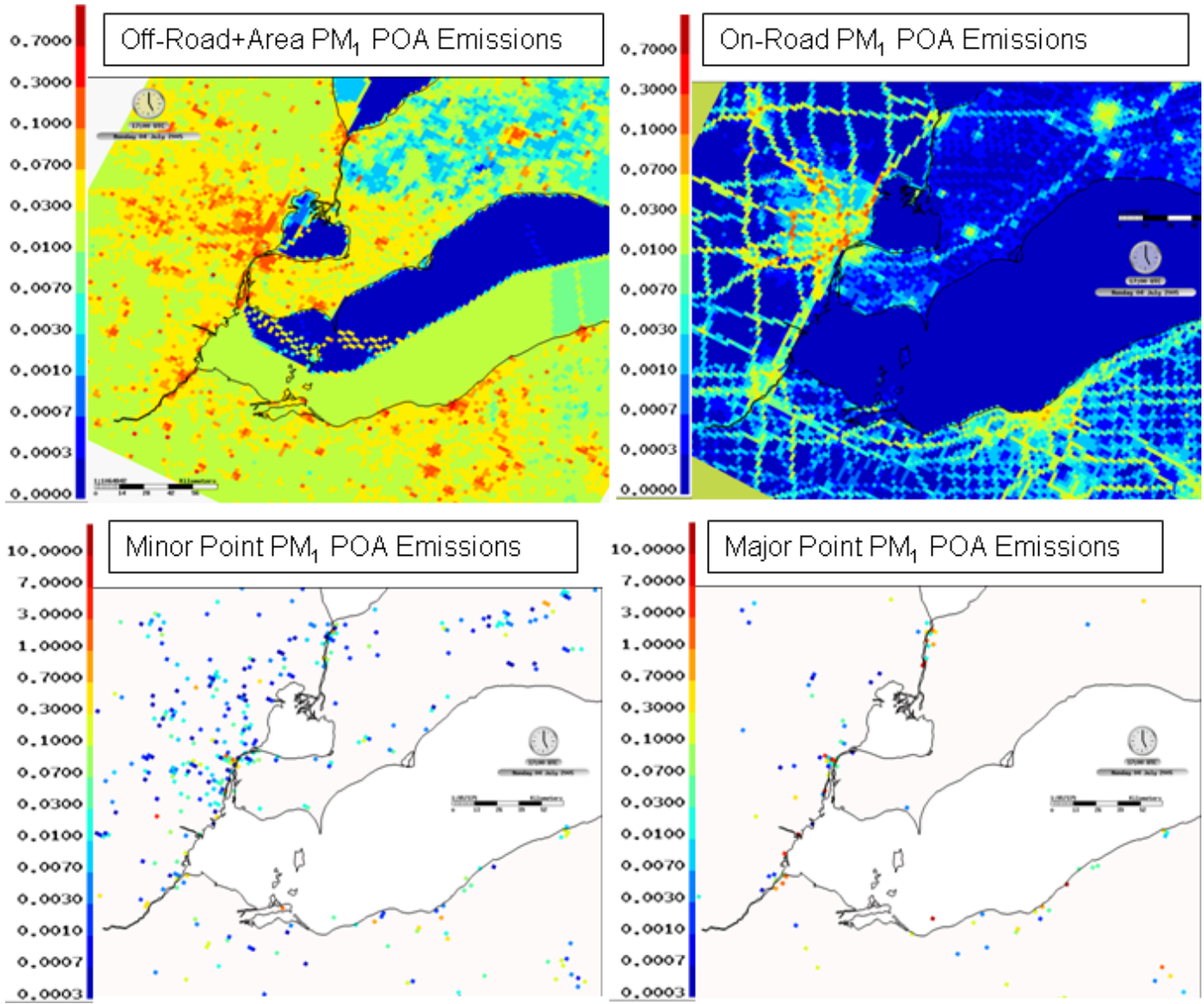

Fig. 3. Example $\mathrm{PM}_{1}$ POA emissions for the $2.5-\mathrm{km}$ innermost domain split into ORAA (upper left), ORM (upper right), minor point (lower left), and major point (lower right) sources on a July Monday at 17:00 UTC (12:00 EST).

estimate daytime planetary boundary layer (PBL) mixing heights (Strawbridge, 2006). No PM composition measurements were made, however, at Ridgetown.

Meteorological measurements were made at a large number of fixed and mobile surface weather stations in the study area. Mesoscale-network measurements included wind speed and direction, dry-bulb and dew-point temperatures, pressure, and solar radiation. These surface measurements, combined with GOES-12 satellite data and radar data from nearby US and Canadian weather radars, allowed the detection of lake-breeze circulations on each day during the intensive observation period based on mesoscale analysis. More details on the meteorological measurements and the lakebreeze detection analysis can be found in Sills et al. (2011).

\section{Results and discussion}

\subsection{POA sources affecting the study area}

Before comparing model predictions and field measurements, it is informative to study the PM emissions inventories for the Canadian province of Ontario, where the BAQS-
Met field study took place, and one of the nearby upwind US states. Indiana was chosen because it is entirely to the southwest of the study region and POA evaluation statistics for periods with meteorological back trajectories from the southwest showed model POA under-predictions. Tables 1 and 2 summarize annual $\mathrm{PM}_{1}$ primary organic carbon (POC) emissions for the 2006 Ontario provincial inventory and the 2005 Indiana state inventory, respectively, where POC is the carbon-only component of POA (i.e., neglecting hydrogen, oxygen, and other constituent elements). These tabulated POC emissions were calculated by applying source-specific PM chemical speciation profiles to annual $\mathrm{PM}_{2.5}$ bulk emissions from individual source types that were identified by source classification category (SCC) codes in the inventories. An additional season-specific column was added to Tables 1 and 2 to report 3-month summer emissions for each POA source. Seasonal scaling factors of 0.5, 0.25, or 0.0 were then applied to the annual POC mass emissions depending on the expected seasonal behaviour of each source type to derive 3-month summer emissions. The $\mathrm{PM}_{1}$ fraction of $\mathrm{PM}_{2.5}$ was then applied to each source stream in the last column (see Sect. 2.2.1). Note one special case: the Indiana 
Table 1. POA emissions inventory for the province of Ontario calculated from the 2006 Canadian $\mathrm{PM}_{2.5}$ NEI with the application of SCC-specific PM chemical speciation profiles and sorted by importance into four aggregate source streams (where 1 ton $=0.9072$ tonnes).

\begin{tabular}{|c|c|c|c|c|}
\hline \multirow{2}{*}{$\begin{array}{l}\text { Source } \\
\text { Stream }\end{array}$} & \multirow{2}{*}{$\begin{array}{l}\text { Ontario } 2006 \text { PM Inventory } \\
\text { Source Category }\end{array}$} & \multicolumn{2}{|c|}{ 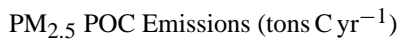 } & \multirow{2}{*}{$\begin{array}{l}\mathrm{PM}_{1} \text { Summer } \\
\text { Source-Stream Contri- } \\
\text { bution } \\
\left(\% \text { Contribution }{ }^{2}\right)\end{array}$} \\
\hline & & Annual & Summer ${ }^{1}$ & \\
\hline On-road Mobile & $\begin{array}{l}\text { Heavy Duty Diesel Vehicles } \\
\text { Light Duty Gasoline Cars } \\
\text { Light Duty Gasoline Trucks } \\
\text { Heavy Duty Gasoline Vehicles } \\
\text { Other On-road Vehicles }\end{array}$ & $\begin{array}{l}299 \\
212 \\
180 \\
40 \\
50\end{array}$ & $\begin{array}{l}75 \mathrm{~A} \\
53 \mathrm{~A} \\
45 \mathrm{~A} \\
10 \mathrm{~A} \\
13 \mathrm{~A}\end{array}$ & $196 \times 0.96(5 \%)$ \\
\hline Off-road Mobile & $\begin{array}{l}\text { Diesel Agricultural Tractors } \\
\text { Diesel Agricultural Combines } \\
\text { Gasoline Pleasure Craft - Outboard } \\
\text { Gasoline Recreational - Snowmobiles } \\
\text { Diesel Trains } \\
\text { Diesel Trucks for Construction, Mining } \\
\text { Other Off-road Mobile Sources }\end{array}$ & $\begin{array}{l}958 \\
96 \\
845 \\
641 \\
221 \\
79 \\
1420\end{array}$ & $\begin{array}{l}479 \mathrm{~B} \\
48 \mathrm{~B} \\
211 \mathrm{~A} \\
0 \mathrm{C} \\
55 \mathrm{~A} \\
20 \mathrm{~A} \\
355 \mathrm{~A}\end{array}$ & $1168 \times 0.96(29 \%)$ \\
\hline Area & $\begin{array}{l}\text { Residential Wood Combustion } \\
\text { Residential Natural Gas } \\
\text { Residential Liquid Petroleum Gas } \\
\text { and Oil } \\
\text { Commercial Fuel Combustion } \\
\text { Electric Utility Fuel Combustion } \\
\text { Agricultural Production - Mostly Crop Drying } \\
\text { and Loading } \\
\text { Charcoal Grilling } \\
\text { Description Unavailable } \\
\text { Dust - Construction } \\
\quad \text { - Agriculture } \\
\quad \text { - Road Fugitives } \\
\text { Waste Disposal Burning } \\
\text { Industrial Metal Production } \\
\text { Industrial Mineral Processes } \\
\text { Industrial Petroleum Refining } \\
\text { Other Area Sources }\end{array}$ & $\begin{array}{l}12,748 \\
948 \\
36 \\
238 \\
15 \\
11 \\
\\
2.690 \\
1.822 \\
292 \\
71 \\
2052 \\
270 \\
733 \\
126 \\
445 \\
14\end{array}$ & $\begin{array}{l}0 \mathrm{C} \\
0 \mathrm{C} \\
0 \mathrm{C} \\
60 \mathrm{~A} \\
4 \mathrm{~A} \\
6 \mathrm{~B} \\
1.345 \mathrm{~B} \\
456 \mathrm{~A} \\
146 \mathrm{~B} \\
36 \mathrm{~B} \\
1026 \mathrm{~B} \\
68 \mathrm{~A} \\
183 \mathrm{~A} \\
32 \mathrm{~A} \\
111 \mathrm{~A} \\
4 \mathrm{~A}\end{array}$ & $3.477 \times 0.73(64 \%)$ \\
\hline Point & Sum of all major and minor stacks & 313 & $78 \mathrm{~A}$ & $78 \times 0.99(2 \%)$ \\
\hline Total & & 25.452 & 4.919 & \\
\hline
\end{tabular}

${ }^{2}$ Percentage Source Stream Contribution (in brackets) calculated using by summing individual summertime contributions in prior column and applying a $\mathrm{PM}_{1}$ fraction of $\mathrm{PM}_{2.5}$ factor $(0.96$ for mobile, 0.73 for area, and 0.99 for point source streams).

ORM emissions in Table 2 were present in the US NEI on a season-specific per-day basis, and thus the 3-month summer estimate was calculated by multiplication by 91 days.

For Ontario, the current NEI indicates that the ORM sector contributes $(196 \times 0.96)$ tons $\mathrm{C} /$ summer of $\mathrm{PM}_{1} \mathrm{POC}$ emissions (5\% of total) with important contributions from both diesel and gasoline engines. The off-road mobile emissions were estimated to be $(1.168 \times 0.96)$ tons $\mathrm{C} /$ summer ( $29 \%$ of total) with the largest contribution coming from diesel tractors. The area sources of $\mathrm{PM}_{1}$ POC emissions are diverse in nature and total $(3.477 \times 0.73)$ tons $\mathrm{C} /$ summer (64\% of total), with charcoal grilling $(1.345 \times 0.73)$, dust sources $(1.208 \times 0.73)$, unavailable $(456 \times 0.73)$, industrial metal production $(183 \times 0.73)$, and industrial petroleum refining $(111 \times 0.73)$ making the largest contributions to the area sources. The minor and major point sources combined totalled $(78 \times 0.99)$ tons $\mathrm{C} /$ summer $(2 \%$ of total). The magnitudes of the POC emissions from area sources, especially from charcoal grilling, dust-related emissions, and off-road tractors, are surprising. Further investigation into the PM chemical profiles (US EPA SPECIATE4.2 database) applied to calculate the $\mathrm{PM}_{2.5}$ POC emissions from charbroiling revealed a POC percentage of $81 \%$ and from the $\mathrm{PM}_{2.5}$ dust emissions revealed POC percentages of $9.7 \%$ for paved 
Table 2. POA inventory for the state of Indiana calculated with the $2005 \mathrm{US} \mathrm{PM}_{2.5}$ emissions inventory with the application of SCC-specific PM chemical speciation profiles and sorted by importance into four aggregate source streams.

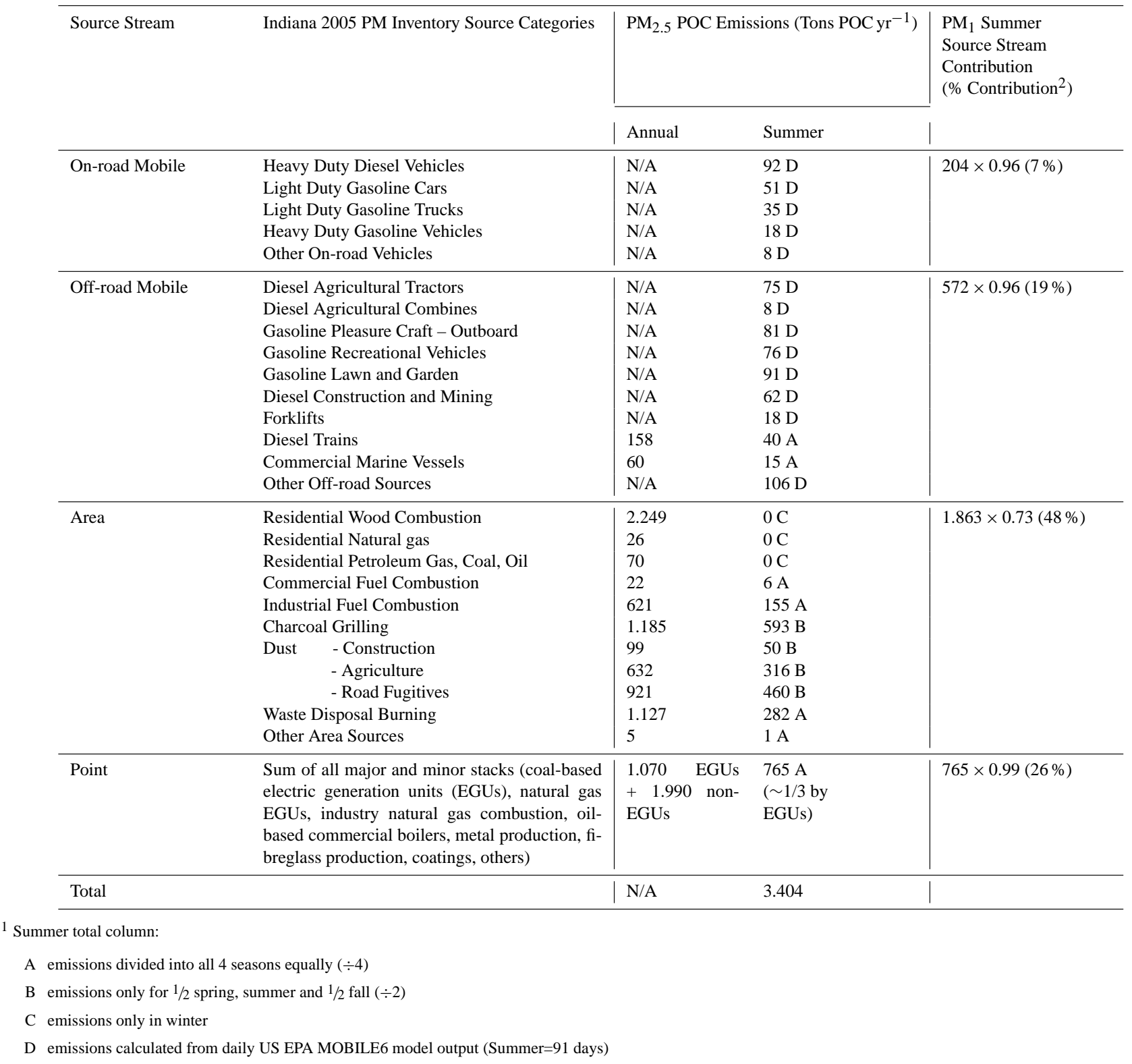

${ }^{2}$ Percentage Source Stream Contribution (in brackets) calculated using by summing individual summertime contributions in prior column and applying a $\mathrm{PM}_{1}$ fraction of $\mathrm{PM}_{2.5}$ factor ( 0.96 for mobile, 0.73 for area, and 0.99 for point source streams).

N/A Not Applicable

roads, $5.5 \%$ for unpaved roads, $4.6 \%$ for construction, and $3.1 \%$ for agricultural activities. For dust, these are relatively small percentages, but when they are applied to the large $\mathrm{PM}_{2.5}$ dust emissions from these source types they yield appreciable $\mathrm{PM}_{2.5}$ POC emissions. Thus, the current Canadian NEI and available $\mathrm{PM}_{2.5}$ speciation profiles lead to the conclusion that area sources are the major contributor to $\mathrm{PM}_{2.5}$ POC emissions, especially on regional scales.

For the AURAMS simulations, emissions were processed slightly differently than those for the results in Tables 1 and 2 .
First, source-specific $\mathrm{PM}_{2.5}$ bulk emissions totals were allocated spatially and temporally with SMOKE using sourcetype-specific spatial and temporal profiles and then were aggregated into four source streams: ORM sources; ORAA sources; and minor and major point sources. Second, the source streams for $\mathrm{PM}_{2.5}$ were allocated chemically into five chemical components (POA, $\mathrm{BC}, \mathrm{SO}_{4}, \mathrm{NO}_{3}, \mathrm{CM}$ ) and into eight particle size bins within AURAMS. The four panels of Fig. 3 show examples of the spatial distribution of $\mathrm{PM}_{1}$ POA emission maps for a July Monday at 17:00 UTC (13:00 EST) 
Table 3. Percentage emission source contributions for different model domains (PM emissions are for PM $\mathrm{P}_{1}$ size range) for July on Monday at 17:00 UTC (12:00 EST).

\begin{tabular}{|c|c|c|c|c|}
\hline Species & $\begin{array}{l}\text { Source } \\
\text { Classification }\end{array}$ & $\begin{array}{r}\text { Detroit } 42 \mathrm{~km} \\
\text { Grid Cell }\end{array}$ & $\begin{array}{r}15 \mathrm{~km} \\
\text { Domain }\end{array}$ & $\begin{array}{r}2.5 \mathrm{~km} \\
\text { Domain }\end{array}$ \\
\hline \multirow[t]{3}{*}{$\mathrm{PM}_{1} \mathrm{POA}$} & On-road & $15 \%$ & $5.8 \%$ & $8.4 \%$ \\
\hline & Off-road + Area & $47 \%$ & $74 \%$ & $74 \%$ \\
\hline & Minor + Major Point & $10 \%+28 \%=\mathbf{3 8} \%$ & $5.5 \%+14.9 \%=\mathbf{2 0} \%$ & $5.2 \%+12 \%=17 \%$ \\
\hline \multirow[t]{3}{*}{$\mathrm{CO}$} & On-road & $47 \%$ & $46 \%$ & $44 \%$ \\
\hline & Off-road + Area & $49 \%$ & $51 \%$ & $53 \%$ \\
\hline & Minor+Major Point & $1.8 \%+2.0 \%=3.8 \%$ & $1.2 \%+1.9 \%=3.1 \%$ & $0.7 \%+2.2 \%=2.9 \%$ \\
\hline \multirow[t]{3}{*}{$\mathrm{PM}_{1} \mathrm{BC}$} & On-road & $54 \%$ & $27 \%$ & $35 \%$ \\
\hline & Off-road+Area & $31 \%$ & $63 \%$ & $57 \%$ \\
\hline & Minor + Major Point & $3.9+10.7 \%=14.6 \%$ & $2.7+7.3 \%=10 \%$ & $2.2 \%+5.3 \%=7.5 \%$ \\
\hline
\end{tabular}

Percentages greater than $20 \%$ are highlighted for emphasis.

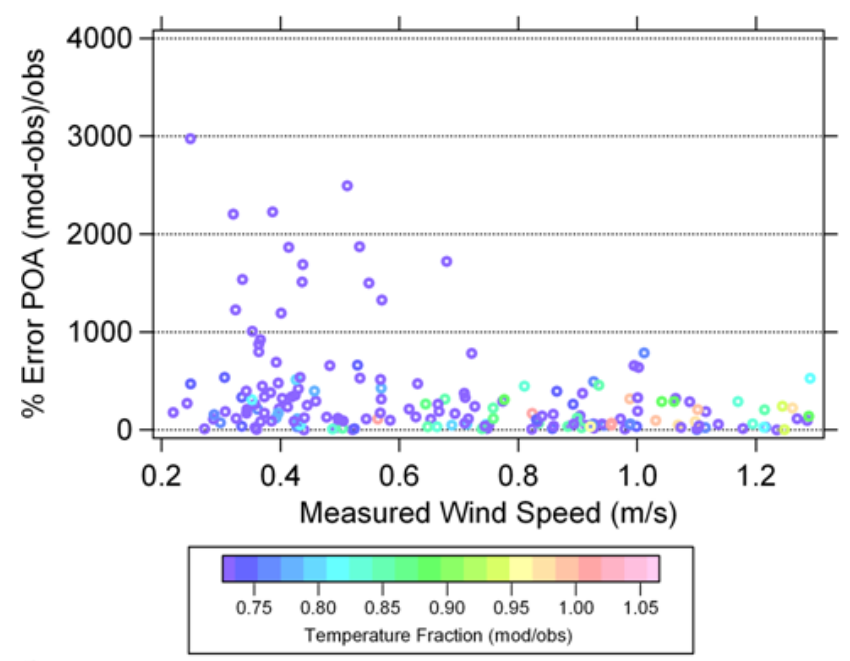

Fig. 4. Model $\mathrm{PM}_{1}$ POA percentage error for nighttime conditions under low winds at Harrow. The colour coding is the ratio of the modeled and measured surface temperature. Under light winds and cooler model surface temperatures, modelled vertical mixing is diminished. Data plotted for nights from 29 June to 11 July 2007.

for ORAA sources, ORM sources, and minor and major point sources. For the ORM emissions the spatial distribution is focused on major highways and urban centres, with higher emissions associated with US highways compared to Canadian highways. For the ORAA sources, the spatial distribution is much more homogeneous, with the exception of lower emissions over the lakes and to the northeast of Bear Creek, and no large discontinuity is observed across the US and Canadian land border. The dominance of the POA area sources suggested by Tables 1 and 2 is evident in Fig. 3, with only the grid cells containing major roadways in the US and to the north of Bear Creek in the Port Huron, MI-Sarnia, ON area having ORM POA emissions greater than the ORAA POA emissions. Figure 3 also shows the POA major and mi- nor point sources. The scales on the point-source plots are an order of magnitude larger than those used for the ORAA and ORM emissions plots. Significant point-source emissions are found in the US to the north, west, and south of the study area, but there are few POA point sources on the Canadian side of the international border and south of Bear Creek. Major point sources are often power generation stations; these have high $\mathrm{NO}_{\mathrm{x}}$ emissions, but due to efficient combustion and to PM control technologies they are typically lower POA emitters (even though POA makes up $16 \%$ of $\mathrm{PM}_{2.5}$ mass in our point-source profiles).

Domain totals for the entire innermost $(2.5-\mathrm{km})$ modelling domain (cf. Fig. 2) show that $74 \%$ of the $\mathrm{PM}_{1}$ POA emissions are from ORAA sources, $12 \%$ from major point sources, $8 \%$ from ORM sources, and $5 \%$ from minor point sources (see Fig. 2 and Table 3). For the entire 15-km middle nested domain, $74 \%$ of the $\mathrm{PM}_{1}$ POA emissions are from ORAA sources, $15 \%$ from major point sources, $6 \%$ from ORM sources, and $5 \%$ from minor point sources. For the single $42 \times 42 \mathrm{~km}$ grid cell of the outermost domain that includes Detroit and downtown Windsor, $47 \%$ of the $\mathrm{PM}_{1}$ POA emissions are from ORAA sources, $28 \%$ from major point sources, $15 \%$ from ORM sources, and $10 \%$ from minor point sources. Thus, according to the Canadian and US NEIs, the Windsor site is strongly impacted by all emissions source streams, including ORM emissions in the Detroit/Windsor urban area and ORAA and point sources in the surrounding region. The Harrow site is impacted largely by ORAA sources, with the exception of those times when it is directly impacted by plumes from point sources or from nearby urban centers (Cleveland and Toledo along the south shore of Lake Erie and Detroit/Windsor to the northwest). At Bear Creek, ORAA and ORM sources in nearby towns and major point sources along the St. Clair River are important local sources, in addition to petrochemical industries to the north in Sarnia, ON, as well as Detroit-Windsor sources to the southwest across Lake St. Clair. 

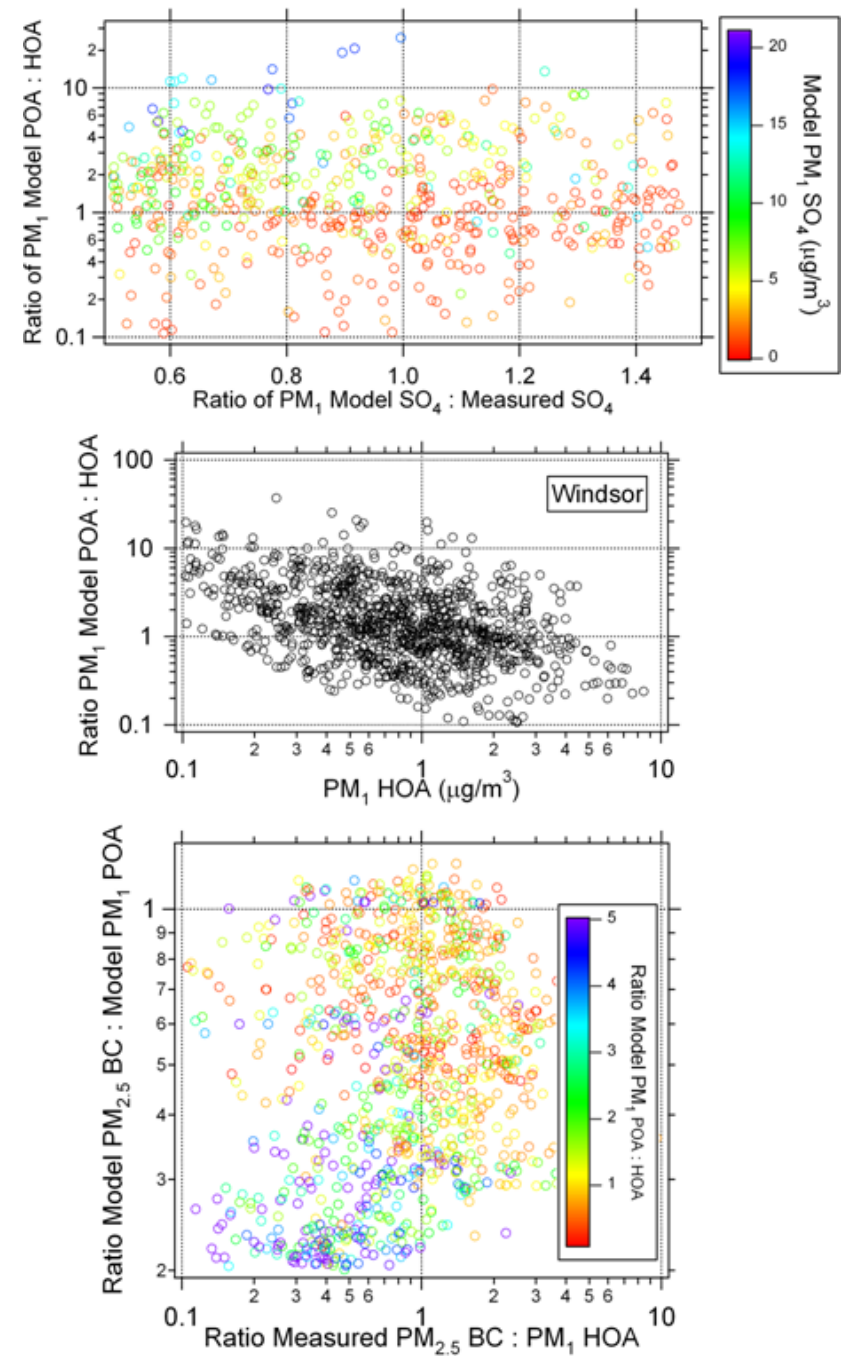

Fig. 5. Scatterplots for Windsor site of (a) ratio of $\mathrm{PM}_{1}$ model POA to $\mathrm{HOA}$ vs. ratio of $\mathrm{PM}_{1}$ model $\mathrm{SO}_{4}$ to measured $\mathrm{SO}_{4}$, colour-coded with model $\mathrm{SO}_{4}$, (b) ratio of $\mathrm{PM}_{1}$ model POA to HOA vs. HOA, and (c) ratio of $\mathrm{PM}_{2.5}$ model $\mathrm{BC}$ to model POA vs. ratio of measured $\mathrm{PM}_{2.5} \mathrm{BC}$ to HOA, colour-coded with ratio of model POA to HOA (yellow is unbiased, red is HOA underprediction, and blue is HOA overprediction). Data plotted for period 29 June to 11 July 2007.

For longer-range transport of pollutants to the study region from the southwest, the emissions in the US Midwest are of significance. This is an important synoptic flow pattern for summertime conditions in the study region (i.e., back of the Bermuda High), and gradient winds from this direction tend to be brisk (Sills et al., 2011). Furthermore, meteorological back trajectories arriving to the study region from the southwest were associated with POA under-predictions (see Supplement section). Table 2 shows the $\mathrm{PM}_{1}$ POC total emissions and percent contributions for the state of Indiana, which is located entirely southwest of the BAQS-Met study area, calculated with the 2005 US PM $_{2.5}$ NEI processed as for Table 1 with the application of SCC-specific PM chemical profiles and $\mathrm{PM}_{1}$ fractions of $\mathrm{PM}_{2.5}$. Note that the population of Indiana in 2005 was about half that of Ontario: 6.3 vs. 12.1 million.

ORM diesel and gasoline combustion emissions in Table 2 are comparable in magnitude and total $(204 \times 0.96)$ tons POC/summer (7\% of total). Off-road mobile emissions total $(572 \times 0.96)$ tons POC/summer $(19 \%$ of total) and are dominated by emissions from diesel tractors, gasoline pleasure craft, gasoline recreational vehicles, and gasoline lawn and garden equipment. Residential wood combustion is large in winter but would not be expected to be significant in summer. Area emissions sources total $(1.863 \times 0.73)$ tons POC/summer $(48 \%$ of total $)$ and are composed largely of dust sources, charcoal grilling, waste disposal, and coal and oil combustion for area industrial processes. Point-source emissions can be split into $(498 \times 0.99)$ tons $\mathrm{POC} /$ summer from industrial processes and $(268 \times 0.99)$ tons POC/summer from electricity generation, largely from coal, for a sum of $(765 \times 0.99)$ tons POC/summer (26\% of total).

Interestingly, in comparing the $\mathrm{PM}_{1} \mathrm{POC}$ Ontario and Indiana inventories, the sum of the on-road and off-road mobile source percentages are very similar: $34 \%$ for Ontario and $26 \%$ of Indiana. Ontario has higher area-source percentages than Indiana (64\% compared to $48 \%$ ) and Indiana has higher point source percentages than Ontario $(26 \%$ compared to $2 \%$ ). This is reasonable given the larger population and land area of Ontario and larger emissions from point sources in the US Midwest and Ohio Valley compared to Ontario, where coal-fired power generation is much less important. The Indiana inventory does give a picture of which POA area sources and point sources are estimated to be important (i.e., according to the US NEI) in terms of contributing to long-range transport of POA into southwestern Ontario. Charcoal grilling and fugitive dust emissions are the two largest POA sources in Indiana. Industrial point sources are diverse and also very important; major emitters include oilbased boilers, metal production, fibreglass production, and coatings production among many other source types. Powergeneration point sources are also more important than in Ontario. ORM sources, on the other hand, are non-negligible but weaker for the midwestern United States, including Indiana.

Table 3 also lists the emissions contributions by source stream for two related carbonaceous species, $\mathrm{CO}$ and $\mathrm{PM}_{2.5}$ BC. For CO emissions in the Detroit/Windsor airshed, ORM sources and ORAA sources are comparable in magnitude while point sources make only a small contribution. For $\mathrm{PM}_{2.5}$ BC emissions in the Detroit/Windsor airshed (i.e., Detroit 42-km grid cell), ORM sources are the dominant source followed by ORAA sources. Point sources are smaller but non-negligible. Collectively, Table 3 illustrates that POA, $\mathrm{CO}$, and $\mathrm{BC}$ have different source signatures. In comparing these species, we cannot assume they have common sources, but they still may provide complementary information on 
Table 4. AURAMS PM 1 POA model performance statistics for the $2.5-\mathrm{km}_{\text {grid }}$ for the urban Windsor site $\left(\right.$ concentrations in $\mu \mathrm{g} \mathrm{m}^{-3}$ ).

\begin{tabular}{lrrr}
\hline PM $_{1}$ POA & $\begin{array}{r}\text { Windsor Daytime } \\
\text { 09:00-14:00 EST }\end{array}$ & $\begin{array}{r}\text { Windsor Evening and } \\
\text { Nighttime }\end{array}$ & $\begin{array}{r}\text { Windsor Rush-Hour } \\
\text { Periods } \\
\end{array}$ \\
& & $18: 00-06: 00$ EST & $\begin{array}{r}06: 00-09: 00 \text { EST } \\
14: 00-18: 00 \text { EST }\end{array}$ \\
\hline Number of points & & 532 & 264 \\
$(15$ min averages) & 194 & 13 days & 13 days \\
\hline Model POA Average \pm Std Dev & 13 days & $2.1 \pm 2.8$ & $1.6 \pm 1.6$ \\
PMF HOA Average \pm Std Dev & $1.1 \pm 0.9$ & $1.0 \pm 1.0$ & $1.4 \pm 2.1$ \\
y-Intercept (model value) & $1.2 \pm 1.0$ & $0.85 \pm 0.16$ & $1.4 \pm 0.1$ \\
Slope & $0.65 \pm 0.09$ & $1.2 \pm 0.12$ & $0.16 \pm 0.05$ \\
Mean Bias (model-measured) & $0.39 \pm 0.06$ & 1.0 & 0.16 \\
Normalized Mean Bias & 0.18 & $+100 \%$ & $+11 \%$ \\
Normalized Mean Error & $+15 \%$ & $140 \%$ & $91 \%$ \\
RMSE & $17 \%$ & 2.7 & 2.3 \\
Correlation, $R$ & 0.31 & 0.41 & 0.20 \\
\hline
\end{tabular}

which sources and/or processes result in model concentration biases.

\subsection{Campaign Statistics for $\mathrm{PM}_{1}$ POA and HOA at Windsor}

Comparing model-derived POA with measurement-derived HOA must be done carefully and with the knowledge that HOA and POA are not identical quantities under all situations. HOA is derived from hydrocarbon-like fragments in the AMS, which are often strongly tied to fossil-fuel combustion but which can also be related to early-generation products of long-carbon-chain precursors (e.g., sesquiterpenes, long-chain alkanes) that become oxidized but retain hydrocarbon character. Similarly, model POA may also contain some emitted oxygenated organic species that could load onto the OOA factors. As shown in Sect. 3.1, the POA emissions inventory also contains a large fraction of OA bound to dust, and it is unlikely that the HOA measurement would capture this source.

Table 4 presents the model $\mathrm{PM}_{1}$ POA performance statistics for the urban Windsor site (see Fig. 1). Statistics are separated into three diurnal periods: daytime (09:00-14:00 EST); nighttime (18:00-06:00 EST); and rush-hour periods (06:0009:00 and 14:00-18:00 EST). The daytime model $\mathrm{PM}_{1}$ POA mean is $1.1 \pm 0.9 \mu \mathrm{g} \mathrm{m}^{-3}$ and compares well with the measured PMF HOA factor mean of $1.2 \pm 1.0 \mu \mathrm{g} \mathrm{m}^{-3}$; however, the model vs. measurement correlation yields a slope of 0.39 , a model y-intercept of $0.65 \mathrm{~g} \mathrm{~m} \mathrm{~m}^{-3}$, and a correlation coefficient, $R$, of 0.43 . The poor correlation likely reflects possible compensating errors in the emissions or a poor model timing of meteorological factors such as frontal passages, boundarylayer stability, and the exact placement of plumes.

The nighttime model $\mathrm{PM}_{1}$ POA mean is $2.1 \pm 2.8 \mu \mathrm{g} \mathrm{m}^{-3}$ with a large standard deviation as compared to the measurement mean of $1.0 \pm 1.0 \mu \mathrm{g} \mathrm{m}^{-3}$. The large standard devia- tion of the model mean likely reflects variations in modelling the nighttime meteorology, especially vertical mixing near the surface, while the positive bias suggests that the model's surface layer may be too stable at night or that nighttime emissions may be too large. Figure 4 presents the $\mathrm{PM}_{1}$ POA percentage error for 15-min averaged data points at Windsor plotted against wind speed for nighttime data only. The colour coding is the ratio of the model to measured surface temperature. At night, the largest overpredictions occurred under light wind conditions (less than $1 \mathrm{~m} \mathrm{~s}^{-1}$ ) when the model was significantly underpredicting surface temperature (blue points), resulting in a model surface layer that was too stable compared to ambient conditions.

The rush-hour model $\mathrm{PM}_{1} \mathrm{POA}$ mean is $1.6 \pm 1.6 \mu \mathrm{g} \mathrm{m}^{-3}$, which compares favourably with the HOA factor of $1.4 \pm 2.1 \mu \mathrm{g} \mathrm{m}^{-3}$. The HOA factor is largest at rush-hour periods compared to other times of the day. The large standard deviation on the measured mean value likely reflects both meteorological variations associated with the vertical mixing in the boundary layer and the greater variability of ORM emissions at this time associated with traffic flow patterns. The y-intercept of the model vs. measurement bestfit line is particularly large at $1.4 \pm 0.1 \mu \mathrm{g} \mathrm{m}^{-3}$. The slope of $0.16 \pm 0.05$ and correlation, $R=0.20$, are also poor. This variability reflected in the low $R$ value could stem from the poor spatial allocation of Canadian ORM emissions by the SMOKE program due to the use of a single spatial surrogate based on a combination of road-network and population distributions, which in hindsight over-weighted by population distribution and under-weighted roadway locations for Ontario and other provinces (see Fig. 3). A more detailed approach that employed six spatial surrogates, three for urban areas and three for rural areas, was used for spatial allocation of the US ORM emissions (Zhang et al., 2010). 
A time series analysis was also performed and is presented in the Supplement section. Specific times are highlighted where POA was overpredicted due to a very stable model surface layer, as well as times when the Windsor site was impacted by power plant plumes and the model tended to overpredict POA.

\subsection{Modelled POA bias and its correlation with indicator ratios for Windsor}

Figure 5a illustrates the ratio of $\mathrm{PM}_{1} \mathrm{POA}$ to HOA plotted against the ratio of $\mathrm{PM}_{1}$ model $\mathrm{SO}_{4}$ to measured $\mathrm{SO}_{4}$ colourcoded as a function of model $\mathrm{SO}_{4}$ concentration at Windsor. Figure $5 \mathrm{a}$ indicates that points that are (1) close to a model $\mathrm{SO}_{4}$ to measured $\mathrm{SO}_{4}$ ratio of unity $( \pm 0.5$ from unity are plotted) and (2) high in model $\mathrm{SO}_{4}$ (e.g., point source plumes) have a ratio of POA:HOA of 10 or higher. This provides further evidence of a model tendency to predict high POA levels in $\mathrm{SO}_{4}$ plumes. For other points with similar ratios of model to measured $\mathrm{SO}_{4}$ close to unity but low model $\mathrm{SO}_{4}$ concentrations (red points), the POA to HOA ratio is quite variable (ranging from unbiased to an underprediction of HOA) and other sources and processes likely play more important roles.

Figure $5 b$ shows a scatter plot of the model POA to HOA ratio vs. the HOA factor mass concentration for Windsor. There is an apparent trend in bias with measured mass concentration. At intermediate HOA levels, the model is less biased; however, it underpredicts at high HOA levels and overpredicts at low HOA levels. This trend could result from issues in the spatial resolution of the model grid at urban scales or from inadequacies with the spatial surrogate fields for ORM and/or ORAA sources in Windsor. This trend, however, is also consistent with the evaporation hypothesis proposed by Robinson et al. (2007) for combustion sources that have undergone significant ambient dilution. At low HOA loading, the model POA evaporation process may be needed to reduce the model over-prediction at Windsor.

Figure $5 \mathrm{c}$ shows a scatter plot of the ratio of model $\mathrm{PM}_{2.5}$ $\mathrm{BC}$ to model POA vs. the ratio of measured $\mathrm{PM}_{2.5} \mathrm{BC}$ to HOA and colour-coded with the ratio of model $\mathrm{PM}_{1} \mathrm{POA}$ to HOA (yellow is less biased, red indicates an HOA underprediction, and blue indicates an HOA overprediction). The ratio of $\mathrm{PM}_{2.5} \mathrm{BC}$ to $\mathrm{HOA}$ is a measure of the importance of diesel and oil combustion sources relative to other sources (e.g., food cooking, soil dust, and coal and wood combustion) since $\mathrm{PM}_{2.5} \mathrm{BC}$ is produced predominantly from diesel combustion sources (e.g., Samaali et al., 2011). For ratios that are low in both model BC:POA and measured BC:HOA (area sources such as soil dust and meat cooking), these points have high ratios of POA to HOA (i.e., POA overpredictions, denoted by blue colours). This is consistent with the hypothesis that the spatial surrogates for these area source types are too uniform and may need more structure at urban scales. Conversely, ratios of model and measured BC/POA that are both large (ORM and ORAA sources of diesel combustion) are colour-coded red, indicating underpredictions in POA from diesel combustion sources.

\subsection{Campaign statistics for $\mathrm{CO}$ and $\mathrm{PM}_{2.5} \mathrm{BC}$ at Windsor}

The model performance for two other carbonaceous species, $\mathrm{CO}$ and $\mathrm{PM}_{2.5} \mathrm{BC}$, may provide additional information on how well the model is performing in terms of meteorology; however, $\mathrm{CO}$ and $\mathrm{PM}_{2.5} \mathrm{BC}$ are unique species with their own modelling challenges. $\mathrm{CO}$ is not simply a longlived passive tracer of combustion, since it is produced as a secondary pollutant from both biogenic and anthropogenic VOCs. $\mathrm{PM}_{2.5} \mathrm{BC}$ is also long-lived and can be influenced by upwind boundary conditions. $\mathrm{PM}_{2.5} \mathrm{BC}$ is more problematic to measure, and three different techniques have been used at the three super-sites (see Sect. 2.3). BC sources can also differ from POA sources (e.g., diesel, fuel oil, and aircraft exhaust emissions are higher in BC than POA; see Fig. 2 in Robinson et al., 2010).

Tables 5 and 6 present the model evaluation statistics at the urban Windsor site for $\mathrm{CO}$ and $\mathrm{PM}_{2.5} \mathrm{BC}$, respectively. During the day, the campaign-mean model CO was calculated from 15-min-average data points. The daytime model CO is significantly overpredicted with a normalized mean bias (NMB) of $134 \%$, a root mean square error (RMSE) of $520 \mathrm{ppbv}$, and a correlation coefficient of $R=0.24$. Conversely, during the day, the campaign-mean model $\mathrm{PM}_{2.5} \mathrm{BC}$, also calculated from 15-min-average data points, was underpredicted, with a NMB of $-48 \%$, a RMSE of $1.4 \mu \mathrm{g} \mathrm{m}^{-3}$, and a correlation coefficient of $R=0.42$. Clearly, the three carbonaceous species (POA, CO, and BC) have considerably different biases, errors, and correlations. The NMB value of POA is considerably better than the NMB values of $\mathrm{CO}$ and $\mathrm{PM}_{2.5} \mathrm{BC}$ during the daytime hours at Windsor: $15 \%$ vs. $134 \%$ and $-48 \%$. The nighttime and rush-hour period statistics are discussed in detail in the Supplement section. In short, they also show large model $\mathrm{CO}$ overpredictions and $\mathrm{PM}_{2.5} \mathrm{BC}$ underpredictions. The $\mathrm{y}$ intercepts (model values) in the POA model-measurement scatter plots for all three time periods are all positive and large compared to mean modelled values. This could result from numerous possible causes, including (1) not enough vertical mixing in the model in locations where there are high emissions, (2) too slow model deposition processes for urban land use, and/or (3) overly uniform spatial allocation of emissions in urban areas compared to actual emissions patterns (e.g., roads vs. human population vs. commercial surrogates).

Overall, vertical mixing appears to be a critical model process impacting the results at the urban site. It is likely that the emissions inventory for $\mathrm{CO}$ is better characterized than $\mathrm{POA}$ or $\mathrm{BC}$, given that $\mathrm{CO}$ emissions per unit activity level are more easily measured and that $\mathrm{CO}$ is chemically and 
physically stable on the time scale of vertical mixing. If we assume our $\mathrm{CO}$ emissions are accurate, then the results may imply that urban-scale vertical mixing is under-predicted in the model. BC has a larger source contribution from mobile emissions, especially diesel combustion, compared to POA and $\mathrm{CO}$. Any change to increase the mobile emissions, especially diesel combustion, would result in an improvement in the model BC negative bias.

\subsection{Campaign statistics for $\mathrm{PM}_{1}$ POA and HOA at Harrow and Bear Creek}

Table 7 summarizes the model $\mathrm{PM}_{1}$ POA performance statistics for the rural Harrow and Bear Creek sites. The daytime model mean at Harrow is $0.3 \pm 0.2 \mu \mathrm{g} \mathrm{m}^{-3}$ compared to a PMF HOA factor of $0.8 \pm 0.7 \mu \mathrm{g} \mathrm{m}^{-3}$. Unlike the urban site, the nighttime averages in the model and measurements are similar to the daytime averages. The averages are within the one standard-deviation of each other. However, the daytime NMB at Harrow is larger than at Windsor whereas the nighttime NMB is smaller (-62\% vs. $15 \%$ in day; $-51 \%$ vs. $100 \%$ at night). Given the rural location of Harrow and its proximity to few ORM emission sources, the variability in the modelled 15-min average may be associated with pollution transport patterns to the site or emissions spatial disaggregation, both of which have large uncertainties. The campaign-averaged $\mathrm{PM}_{1}$ POA under-prediction may be a result of biases in the ORAA inventory or difficulties with the model consistently representing the transport pathways of pollutants to Harrow. The model POA y-intercepts, slope, and correlation are also poor. In the summer Harrow is often impacted by lake-breeze fronts, which are difficult to model accurately both spatially and temporally (Levy et al., 2010; Makar et al., 2010a).

The Supplement section shows time series of measured $\mathrm{PM}_{1} \mathrm{HOA}$ and AURAMS $\mathrm{PM}_{1}$ POA for Harrow. In short, the model does not capture the magnitude of the largest HOA maxima, whereas the lowest background concentrations are captured reasonably well by the model.

Interestingly, the Bear Creek model $\mathrm{PM}_{1} \mathrm{POA}$ mean is similar to Harrow's while the Bear Creek measured HOA mean is much smaller than Harrow's. Like Harrow there is little difference between daytime and nighttime measured averages at Bear Creek, but the Bear Creek daytime model yintercept, slope, NMB, and correlation values are much better than the corresponding values for Harrow. This may be a reflection of Bear Creek being influenced by fewer and different sources than Windsor and Harrow during the study. The dominant wind direction during the 3-week study was from the northwest (Sills et al., 2011), and this direction has few upwind point and urban sources. On the other hand, relative to Bear Creek, Harrow is situated downwind of the Detroit/Windsor urban area for northwesterly flow. In addition, the location of Bear Creek is such that for any wind from the NW-to-SW quadrant, the location will be impacted by

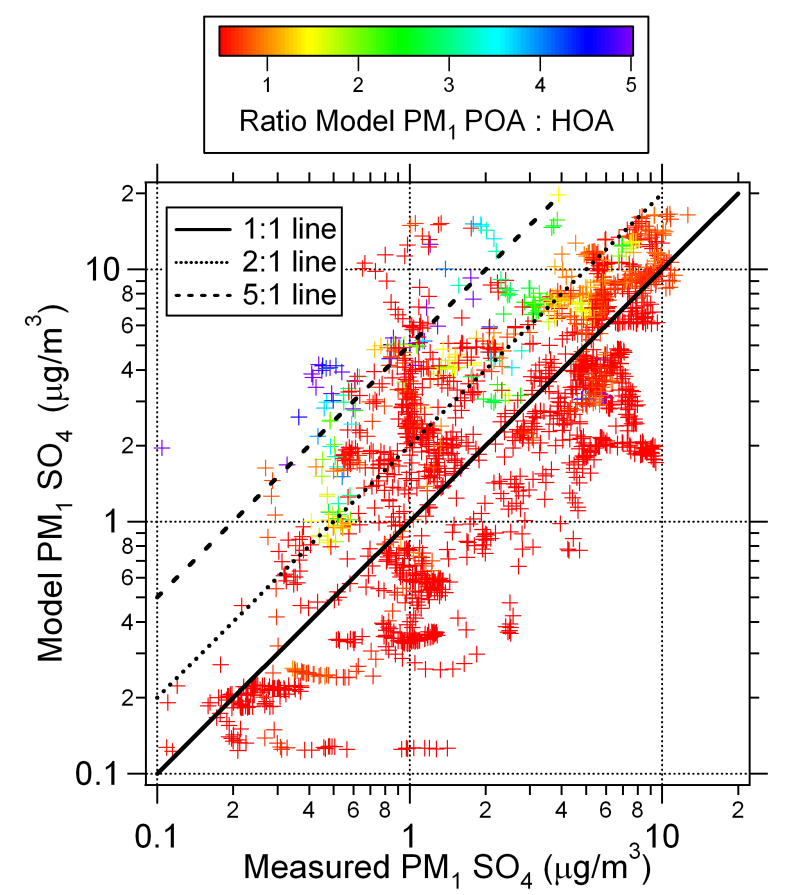

Fig. 6. Correlation of modeled $\mathrm{SO}_{4}$ and measured $\mathrm{SO}_{4}$ at Harrow, coloured-coded as a function of the ratio of model POA to HOA, for the period from 19 June to 10 July 2007.

emissions from the US NEI, which are arguably better characterized than the Canadian NEI, especially in the application of spatial surrogates since US emissions are reported at the county level, which is a much finer spatial scale than the Canadian emissions, which are reported at the much larger provincial level and hence which are much more sensitive to the suitability and representativeness of the spatial surrogates that are used. The transport pathways may also be better represented in the model at Bear Creek. The correlation does worsen at night for Bear Creek, but the model remains unbiased there. This may be a reflection of predicting the stability of the nocturnal boundary layer and the drainage flow of plumes from local sources along the St. Clair River.

\subsection{Campaign statistics for $\mathrm{CO}$ and $\mathrm{PM}_{2.5} \mathrm{BC}$ at Harrow and Bear Creek}

Tables 8 and 9 list campaign-period performance statistics for $\mathrm{CO}$ and $\mathrm{PM}_{2.5} \mathrm{BC}$ at Harrow and Bear Creek (cf. Tables 5 and 6 for Windsor). CO was largely unbiased at both sites for both daytime and nighttime periods. The correlation coefficient, $R$, for $\mathrm{CO}$ is also significantly improved for these two rural sites compared to the urban Windsor site. The good agreement for $\mathrm{CO}$ at these two rural sites suggests that longrange transport and boundary conditions are not the cause of the poor $\mathrm{CO}$ model results at Windsor. This reduces the number of possible sources of model $\mathrm{CO}$ overprediction at Windsor, but still leaves spatial and temporal allocation of 
emissions and/or vertical mixing of emissions as possible explanations.

At Harrow, $\mathrm{PM}_{2.5} \mathrm{BC}$ was underpredicted to a similar degree as POA (NMB $=-73 \%$ during day and $-67 \%$ at night vs. $-62 \%$ and $-51 \%$ ). At Bear Creek, $\mathrm{PM}_{2.5} \mathrm{BC}$ was also significantly underpredicted ( $\mathrm{NMB}=-71 \%$ during day and $-67 \%$ at night), but the daytime correlation for $\mathrm{BC}$ at Bear Creek was the best of all three species for the three sites $(R=0.72)$. In fact, $\mathrm{PM}_{2.5} \mathrm{BC}$ was consistently and significantly underpredicted at Windsor, Bear Creek, and Harrow, suggesting a problem with the magnitude of the emissions. Interestingly, at Harrow none of the three carbonaceous species displayed significant differences between day and night. The behaviour of POA and $\mathrm{CO}$ were quite different in the statistics at Harrow, while POA and BC had similar statistics in terms of NMB and correlation.

Calculations of measured and model $\mathrm{PM}_{1}$ sulphate for the entire period at Harrow showed only a small NMB of $14 \%$. The model and measured means were $3.3 \mu \mathrm{g} \mathrm{m}^{-3}$ and $2.8 \mu \mathrm{g} \mathrm{m}^{-3}$, respectively. Figure 6 shows a scatter plot for model and measured $\mathrm{PM}_{1} \mathrm{SO}_{4}$ at Harrow colour-coded as a function of the ratio of $\mathrm{PM}_{1}$ POA to HOA. Points with model POA to HOA ratios greater than 1.5 tend to fall on or above the model and measurement $\mathrm{SO}_{4}$ 1:1 line. This suggests that for some model $\mathrm{SO}_{4}$ plumes, the POA is overpredicted (e.g., 26 June, 12:00-13:00 EST). This likely reflects the CTM's ability to predict the placement and vertical mixing of point source plumes. An examination of the AURAMS surface $\mathrm{SO}_{4}$ and POA distributions on 26 June (not shown) suggests Harrow was influenced by longer-range transport of plumes from point sources along the southern shore of Lake Erie. Interestingly, there are also some points close to the $\mathrm{PM}_{1} \mathrm{SO}_{4}$ model vs. measurement 1:1 line which are high in POA to HOA ratio (e.g., 17 June, 13:00-14:00 EST). This suggests that the point-source PM chemical speciation profile used by SMOKE may overweight the POA fraction for sources impacting Harrow. An examination of the AURAMS surface $\mathrm{SO}_{4}$ and POA distributions (not shown) suggests Harrow was influenced from point sources along the Detroit River on 17 June; however, the model fields also suggest significant convective activity and showers on this day and this complicates further analysis.

The fact that $\mathrm{CO}$ is much better predicted at the two rural sites whereas POA is often underpredicted at Harrow does support the hypothesis presented earlier that too weak vertical mixing at the urban site may result in $\mathrm{CO}$ overpredictions there. The air masses impacting Harrow have more time for vertical mixing out of the lowest model layer and thus are not as sensitive to mixing as at the urban Windsor site. By contrast, POA may be underpredicted at Harrow due to insufficient upwind urban emissions. The next section will perform a more diagnostic evaluation of this hypothesis for specific case study times at Harrow and Bear Creek.

\subsection{Case studies}

In this section of the study, we examined four types of case studies (urban influence, biomass burning, transport from the southwest, and transport from the northwest) to better understand the sources of model POA bias under different daytime conditions, especially the times for POA under-prediction at Harrow. Case-study periods were identified based on analysis of high-resolution meteorological back trajectories for Harrow and Bear Creek, and, for Harrow, the single-particle component-based factor analysis results from McGuire et al. (2011). Cases for air masses transported from the southwest and northwest are discussed in the Supplement section. In short, the model showed underpredictions in model POA with wind direction from the southwest and good agreement for air masses from the northwest. The mesoscale analyses and high-resolution back trajectories are included in the Supplement section for all cases. The spatial distributions of the model vertical wind speed at $390 \mathrm{~m}$ are also included in the Supplement section for one case to compare with the positions of the lake-breeze fronts on the mesoscale analysis.

Note that 4 July 2007 was removed as a potential casestudy day due to too much model convective instability compared to radar. A model mesoscale circulation swept through the Bear Creek region that was not observed in the winds at the mesonet sites. 30 June was also removed due to different wind directions observed and modelled near Bear Creek. At times, the position of the Lake Erie lake-breeze front was misplaced by the model (e.g., 6 July), which is important in determining which air masses were sampled at Harrow. A detailed discussion of meteorological impacts on air quality is beyond the scope of this paper. Case studies are only presented in detail here for periods when the model was felt to represent the transport accurately from a comparison with the mesoscale analysis. Sulphate will be used for further diagnosis in the case studies.

\subsubsection{Detroit/Windsor urban-influenced air masses arriving at Harrow and Bear Creek}

Table 10 lists the two representative case-study (CS) periods for Detroit/Windsor urban-influenced air masses arriving at Harrow (21 June) and Bear Creek (8 July). At Harrow, this corresponds to the "Organic" factor period identified in McGuire et al. (2011). Single-particle ATOFMS PMF analysis identified the likely source of the organics as fuel combustion. The "Organic" factor also correlated well with gas-phase $\mathrm{NO}_{2}$ and $\mathrm{PM}_{2.5} \mathrm{BC}$, which are both fuel combustion tracers. Examination of the measured particle size distribution for this factor revealed geometric mean diameters in the range $0.55-0.58 \mu \mathrm{m}$, which together suggests the "Organic" factor may be related to secondary organic aerosol. The aerosol mass spectra indicated oxidized organic species and a fragmentation pattern consistent with aromatic molecular groups. Thus, the smaller Aitken-mode HOA particles 
Table 5. AURAMS CO model performance statistics for the $2.5-\mathrm{km}$ grid for the urban Windsor site (mixing ratios in ppbv).

\begin{tabular}{lrrr}
\hline CO & $\begin{array}{r}\text { Windsor Daytime } \\
\text { 09:00-14:00 EST }\end{array}$ & $\begin{array}{r}\text { Windsor Evening } \\
\text { and Nighttime } \\
18: 00-06: 00 \text { EST }\end{array}$ & $\begin{array}{r}\text { Windsor Rush-Hour } \\
\text { Periods 06:00-09:00 EST } \\
14: 00-18: 00 \text { EST }\end{array}$ \\
\hline Number of points & 189 & 535 & 262 \\
$(15$ min averages) & 13 days & 13 days & 13 days \\
\hline Model CO Average \pm Std Dev & $592 \pm 405$ & $566 \pm 393$ & $665 \pm 539$ \\
Meas. CO Average \pm Std Dev & $253 \pm 145$ & $285 \pm 219$ & $301 \pm 318$ \\
y-Intercept (model value) & $420 \pm 58$ & $346 \pm 25$ & $474 \pm 43$ \\
Slope & $0.68 \pm 0.20$ & $0.77 \pm 0.07$ & $0.64 \pm 0.10$ \\
Mean Bias (model-measured) & +339 & +281 & +364 \\
Normalized Mean Bias & $+134 \%$ & $+99 \%$ & $+121 \%$ \\
Normalized Mean Error & $142 \%$ & $107 \%$ & $137 \%$ \\
RMSE & 520 & 455 & 628 \\
Correlation, $R$ & 0.24 & 0.43 & 0.38 \\
\hline
\end{tabular}

Table 6. AURAMS $\mathrm{PM}_{2.5} \mathrm{BC}$ model performance statistics for the $2.5-\mathrm{km}_{\text {grid }}$ for the urban Windsor site (concentrations in $\mu \mathrm{g} \mathrm{m}^{-3}$ ).

\begin{tabular}{lrrr}
\hline $\mathrm{PM}_{2.5} \mathrm{BC}$ & $\begin{array}{r}\text { Windsor Daytime } \\
\text { 09:00-14:00 EST }\end{array}$ & $\begin{array}{r}\text { Windsor Evening } \\
\text { and Nighttime } \\
18: 00-06: 00 \text { EST }\end{array}$ & $\begin{array}{r}\text { Windsor Rush-Hour } \\
\text { Periods 06:00-09:00 EST } \\
14: 00-18: 00 \text { EST }\end{array}$ \\
\hline Number of points & 190 & 535 & 263 \\
$(15$ min averages) & 13 days & 13 days & 13 days \\
\hline Model BC Average \pm Std Dev & $0.70 \pm 0.60$ & $0.83 \pm 0.82$ & $0.88 \pm 0.88$ \\
Meas BC Average \pm Std Dev & $1.3 \pm 1.3$ & $1.4 \pm 1.5$ & $1.3 \pm 1.4$ \\
y-Intercept (model value) & $0.45 \pm 0.06$ & $0.50 \pm 0.04$ & $0.36 \pm 0.06$ \\
Slope & $0.19 \pm 0.03$ & $0.24 \pm 0.02$ & $0.41 \pm 0.03$ \\
Mean Bias (model-measured) & -0.65 & -0.57 & -0.38 \\
Normalized Mean Bias & $-48 \%$ & $-41 \%$ & $-30 \%$ \\
Normalized Mean Error & $59 \%$ & $61 \%$ & $55 \%$ \\
RMSE & 1.38 & 1.47 & 1.12 \\
Correlation, $R$ & 0.42 & 0.43 & 0.64 \\
\hline
\end{tabular}

likely originated from sources that were also rich in SOA precursor gases. At Harrow, the AMS HOA factor was $17 \%$ of the AMS OA measured mass concentration. The HOA factor $\left(1.4 \mu \mathrm{g} \mathrm{m}^{-3}\right.$; Table 10$)$ was also larger than the 23-day daytime average $\left(0.8 \mu \mathrm{g} \mathrm{m}^{-13}\right.$; Table 7$)$. Back trajectories on 21 June were also consistent with moderate NNW gradient winds and air parcels passing over southern Detroit before reaching Harrow (Section Supplement, CS 1a). The NMB value for $\mathrm{PM}_{1} \mathrm{POA}$ was $-81 \%$. The AURAMS $\mathrm{PM}_{1} \mathrm{POA}$ surface distribution map (Fig. 7) shows the Harrow site on 21 June (10:00EST) being impacted by an electric-power generation station plume (Trenton) but little else. From the AURAMS POA surface distribution, the modelled downtown Detroit plume from the highest density of ORM emissions passed well north of Harrow. The mesoscale analysis shows that measured wind directions at Harrow and nearby sites were consistent with the model winds, and the PBL heights derived from model vertical profiles were consistent with the Ridgetown LIDAR measurements.
For other species, the model and measured $\mathrm{PM}_{1} \mathrm{SO}_{4}$ concentrations were 1.9 and $1.3 \mu^{-3} \mathrm{~m}^{-3}$, respectively, over the 5-h daytime period, markedly lower than the model and measured campaign means for Harrow of 3.3 and $2.8 \mu \mathrm{g} \mathrm{m}^{-3}$. There was a short-lived maximum in the modelled $\mathrm{SO}_{4}$ when the Trenton plume passed over Harrow ( $\sim 30$ min duration): however, the remaining 4.5 -h period saw relatively low and constant $\mathrm{SO}_{4}$ levels in both model and measurements. The $\mathrm{NMB}$ for $\mathrm{CO}$ was low at $-17 \%$ but the NMB for $\mathrm{PM}_{2.5} \mathrm{BC}$ was $-84 \%$, similar to that for $\mathrm{PM}_{1} \mathrm{POA}(\mathrm{NMB}=-81 \%)$. The source region in southern Detroit is heavily industrialized. The predominant wind direction in the region for the campaign was from the west to north-west (Sills et al., 2011). Given this prevailing wind sector, this case provides further evidence for a common synoptic pattern contributing to the campaign-mean negative $\mathrm{PM}_{1} \mathrm{POA}$ bias at Harrow.

At Bear Creek on the afternoon of 8 July, the HOA factor was also larger than average $\left(1.0 \mathrm{vs} .0 .3 \mu \mathrm{g} \mathrm{m}^{-13}\right)$, winds were moderate from the $\mathrm{SW}$, and back trajectories showed 
Table 7. AURAMS PM 1 POA model performance statistics for the 2.5-km grid for the rural Harrow and Bear Creek sites (concentrations in $\left.\mu \mathrm{g} \mathrm{m}^{-3}\right)$.

\begin{tabular}{|c|c|c|c|c|}
\hline PM1 POA & $\begin{array}{r}\text { Harrow } \\
\text { Daytime } \\
09: 00-18: 00 \text { EST }\end{array}$ & $\begin{array}{r}\text { Harrow } \\
\text { Night-Time } \\
\text { 18:00-09:00 EST }\end{array}$ & $\begin{array}{r}\text { Bear Creek } \\
\text { Daytime } \\
09: 00-18: 00 \text { EST }\end{array}$ & $\begin{array}{r}\text { Bear Creek } \\
\text { Nighttime } \\
\text { 18:00-09:00 EST }\end{array}$ \\
\hline Number of points & $\begin{array}{r}1828 \text { (15 min avges }) \\
23 \text { days }\end{array}$ & $\begin{array}{r}3480 \\
23 \text { days }\end{array}$ & $\begin{array}{r}297 \text { (3 min avges) } \\
12 \text { days }\end{array}$ & $\begin{array}{r}538 \\
12 \text { days }\end{array}$ \\
\hline Model POA Average \pm Std Dev & $0.3 \pm 0.2$ & $0.4 \pm 0.3$ & $0.24 \pm 0.21$ & $0.36 \pm 0.23$ \\
\hline PMF HOA Average \pm Std Dev & $0.8 \pm 0.7$ & $0.9 \pm 0.9$ & $0.31 \pm 0.39$ & $0.32 \pm 0.31$ \\
\hline y-Intercept (model value) & 0.246 & 0.336 & 0.14 & 0.29 \\
\hline Slope & 0.058 & 0.116 & 0.32 & 0.21 \\
\hline Mean Bias & -0.48 & -0.45 & -0.07 & 0.039 \\
\hline Normalized Mean Bias & $-62 \%$ & $-51 \%$ & $-23 \%$ & $+12 \%$ \\
\hline Normalized Mean Error & $69 \%$ & $69 \%$ & $63 \%$ & $73 \%$ \\
\hline RMSE & 0.87 & 0.93 & 0.32 & 0.34 \\
\hline Correlation, $R$ & 0.23 & 0.32 & 0.58 & 0.28 \\
\hline
\end{tabular}

Table 8. AURAMS CO model performance statistics for the $2.5-\mathrm{km}$ grid for the rural Harrow and Bear Creek sites (concentrations in ppbv).

\begin{tabular}{|c|c|c|c|c|}
\hline $\mathrm{CO}$ & $\begin{array}{r}\text { Harrow } \\
\text { Daytime } \\
09: 00-18: 00 \text { EST }\end{array}$ & $\begin{array}{r}\text { Harrow } \\
\text { Nighttime } \\
18: 00-09: 00 \text { EST }\end{array}$ & $\begin{array}{r}\text { Bear Creek } \\
\text { Daytime } \\
09: 00-18: 00 \text { EST }\end{array}$ & $\begin{array}{r}\text { Bear Creek } \\
\text { Nighttime } \\
\text { 18:00-09:00 EST }\end{array}$ \\
\hline Number of points & $\begin{array}{r}1514 \text { (15 min avges }) \\
23 \text { days }\end{array}$ & $\begin{array}{r}3139 \\
23 \text { days }\end{array}$ & $\begin{array}{r}227 \text { (3 min avges) } \\
12 \text { days }\end{array}$ & $\begin{array}{r}477 \\
12 \text { days }\end{array}$ \\
\hline Model CO Average \pm Std Dev & $180 \pm 49$ & $192 \pm 62$ & $172 \pm 44$ & $172 \pm 44$ \\
\hline Meas. CO Average \pm Std Dev & $197 \pm 87$ & $204 \pm 82$ & $199 \pm 97$ & $210 \pm 93$ \\
\hline y-Intercept (model value) & $129 \pm 3$ & $111 \pm 3$ & $129 \pm 6$ & $103 \pm 4$ \\
\hline Slope & $0.26 \pm 0.01$ & $0.40 \pm 0.01$ & $0.22 \pm 0.03$ & $0.33 \pm 0.02$ \\
\hline Mean Bias (model-measured) & -17 & -12 & -26 & -38 \\
\hline Normalized Mean Bias & $+2 \%$ & $-6 \%$ & $-13 \%$ & $-11 \%$ \\
\hline Normalized Mean Error & $28 \%$ & $25 \%$ & $26 \%$ & $24 \%$ \\
\hline RMSE & 79 & 73 & 89 & 80 \\
\hline Correlation, $R$ & 0.46 & 0.53 & 0.49 & 0.69 \\
\hline
\end{tabular}

air passing over industrial southern Detroit and Windsor before reaching Bear Creek (see Supplement section, CS 1b). The model $\mathrm{PM}_{1}$ POA mean concentration for the 4-h period on July 8 was similar to the 23 -day average (0.32 vs. $0.24 \mu \mathrm{g} \mathrm{m}^{-3}$ ) and the model $\mathrm{PM}_{1}$ POA NMB was $-67 \%$. The AURAMS $\mathrm{PM}_{1}$ POA distribution map (Fig. 7) for 8 July (13:00 EST) does not show a well-defined plume being transported from southern Detroit/Windsor. The model vertical cross section parallel to the surface wind direction at Bear Creek clearly showed some surface downtown Detroit urban emissions and their vertical mixing (Fig. 7). The model mixed layer was well developed at Bear Creek by the afternoon and vertical mixing was diluting the downwind plume. The Ridgetown LIDAR measurements were not available at this time; however, the model-derived PBL height was similar to the campaign-mean afternoon LIDAR PBL height of $1600 \mathrm{~m}$. The measured HOA was consistently higher than the campaign-mean value for more than four hours, suggest- ing the measurements were not due to a passing localized plume. The NMB values for $\mathrm{CO}$ and $\mathrm{PM}_{2.5} \mathrm{BC}$ of $-21 \%$ and $-71 \%$, respectively, were similar to the above Harrow case. The similar NMB values for $\mathrm{PM}_{2.5} \mathrm{BC}$ and $\mathrm{PM}_{1}$ POA may suggest a common cause for the underpredictions (e.g., areasource spatial disaggregation for urban areas or emissions activity levels for urban diesel sources). The good agreement for CO may suggest that vertical mixing issues at the urban site may lose their impact at the rural sites due to the longer transport times for mixing to take place (Table 5 vs. Table 8).

It is interesting that the campaign-mean daytime model bias for $\mathrm{PM}_{1} \mathrm{POA}$ is small at the Windsor urban location, but the 21 June and 8 July cases both show a significant model POA underprediction when the Detroit/Windsor plume is impacting one of the rural sites. The mesoscale analyses for both cases suggest the model is representing the meteorology reasonably well (see Supplement section, CS 1a,b), and the wind fields are straightforward for both days, which suggest 
Table 9. AURAMS $\mathrm{PM}_{2.5} \mathrm{BC}$ model performance statistics for the 2.5-km grid for the rural Harrow and Bear Creek sites (concentrations in $\left.\mu \mathrm{g} \mathrm{m}^{-3}\right)$.

\begin{tabular}{|c|c|c|c|c|}
\hline $\mathrm{PM}_{2.5} \mathrm{BC}$ & $\begin{array}{r}\text { Harrow } \\
\text { Daytime } \\
09: 00-18: 00 \text { EST }\end{array}$ & $\begin{array}{r}\text { Harrow } \\
\text { Nighttime } \\
18: 00-09: 00 \text { EST }\end{array}$ & $\begin{array}{r}\text { Bear Creek } \\
\text { Daytime } \\
\text { 09:00-18:00 EST }\end{array}$ & $\begin{array}{r}\text { Bear Creek } \\
\text { Nighttime } \\
\text { 18:00-09:00 EST }\end{array}$ \\
\hline Number of points & $\begin{array}{r}239 \text { (105 min avges }) \\
23 \text { days }\end{array}$ & $\begin{array}{r}139 \\
23 \text { days } \\
\end{array}$ & $\begin{array}{r}295 \text { (3 min avges) } \\
12 \text { days }\end{array}$ & $\begin{array}{r}532 \\
12 \text { days } \\
\end{array}$ \\
\hline Model BC Average \pm Std Dev & $0.16 \pm 0.11$ & $0.19 \pm 0.12$ & $0.11 \pm 0.09$ & $0.15 \pm 0.09$ \\
\hline Meas BC Average \pm Std Dev & $0.60 \pm 0.28$ & $0.61 \pm 0.27$ & $0.38 \pm 0.26$ & $0.46 \pm 0.32$ \\
\hline y-Intercept (model value) & $0.070 \pm 0.016$ & $0.099 \pm 0.02$ & $0.018 \pm 0.006$ & $0.090 \pm 0.006$ \\
\hline Slope & $0.15 \pm 0.02$ & $0.15 \pm 0.04$ & $0.24 \pm 0.01$ & $0.14 \pm 0.01$ \\
\hline Mean Bias (model-meas) & -0.44 & -0.42 & -0.27 & -0.31 \\
\hline Normalized Mean Bias & $-73 \%$ & $-67 \%$ & $-71 \%$ & $-67 \%$ \\
\hline Normalized Mean Error & $73 \%$ & $69 \%$ & $71 \%$ & $68 \%$ \\
\hline RMSE & 0.50 & 0.49 & 0.34 & 0.42 \\
\hline Correlation, $R$ & 0.39 & 0.33 & 0.72 & 0.46 \\
\hline
\end{tabular}

Table 10. Detroit-Windsor urban-influenced air masses arriving at Harrow and Bear Creek.

\begin{tabular}{|c|c|c|c|c|c|c|c|c|}
\hline Date (EST) & $\begin{array}{l}\text { Model POA } \\
\text { HOA NMB } \\
\text { RMSE }\end{array}$ & $\mathrm{HOA} / \mathrm{OA}$ & Winds & Meteorology & $\begin{array}{l}\text { Model BC } \\
\text { Meas. BC } \\
\text { NMB } \\
\text { RMSE }\end{array}$ & $\begin{array}{l}\text { Model CO } \\
\text { Meas. CO } \\
\text { NMB } \\
\text { RMSE }\end{array}$ & $\begin{array}{l}\text { Model SO4 } \\
\text { Meas. SO4 } \\
\text { NMB } \\
\text { RMSE }\end{array}$ & $\begin{array}{l}\text { PMF Source } \\
\text { Description }\end{array}$ \\
\hline $\begin{array}{l}\text { Bear Creek } \\
8 \text { July, } \\
\text { 10:00-14:20 }\end{array}$ & $\begin{array}{l}0.32 \pm 0.10 \\
0.96 \pm 0.23 \\
-67 \% \\
0.66 \mu \mathrm{g} \mathrm{m}^{-3}\end{array}$ & $6 \%$ & SW moderate & $\begin{array}{l}\text { Winds and } \\
\text { PBL heights } \\
\text { predicted well }\end{array}$ & $\begin{array}{l}0.15 \\
0.53-71 \% \\
0.38 \mu \mathrm{g} \mathrm{m}^{-3}\end{array}$ & $\begin{array}{l}194 \\
245 \\
-21 \% \\
53 \text { ppbv }\end{array}$ & $\begin{array}{l}2.3 \\
13.0 \\
83 \% \\
10.6 \mu \mathrm{g} \mathrm{m}^{-3}\end{array}$ & $\begin{array}{l}\text { South Detroit } \\
\text { and Windsor } \\
\text { origin }\end{array}$ \\
\hline
\end{tabular}

that the POA emissions were more likely under-represented than dispersion was over-represented, especially from the heavily industrialized southern Detroit source region as compared to the more ORM-dominated site in Windsor. Another possibility is that the oxidation of intermediate volatile organic compounds (IVOCs: e.g., long-chain alkanes) may be occurring during transport to the rural sites and weakly oxidized early-generation IVOC products may be condensing and then classified as HOA in the PMF analysis. Evidence for HOA factor mass generated from the oxidation of crude oil evaporative IVOC emissions in the Gulf of Mexico (e.g., long-chain alkanes) was recently found by de Gouw et al. (2011).

\subsubsection{Intermittent biomass-burning}

Table 11 lists two cases when Harrow sampled biomassburning-influenced air. The model $\mathrm{PM}_{1}$ POA means were low, as AURAMS did not account for emissions from biomass-burning events. The single-particle ATOFMS PMF analysis on 6 July showed influence from a "biomassburning" factor (McGuire et al., 2011). The unit resolution AMS PMF spectra were ambiguous for the biomassburning periods (Slowik et al., 2011) and the factorization routine did not calculate a unique BBOA factor. However, it is likely that some non-quantified amount of the HOA is related to biomass burning as HOA does correlate with acetonitrile and potassium (Slowik et al., 2011), which are tracers for biomass burning (Aiken et al., 2010). HOA also correlates with gaseous aromatics so a mix of influences is likely. Model comparison with the HOA factor results in NMB values of $-71 \%$ and $-94 \%$ for the 7 an 6 July periods, respectively. The mesoscale analysis and high-resolution back trajectories can be found in the Supplement section (see CS $3 a, b)$. These cases also contributed to the overall model $\mathrm{PM}_{1}$ POA underprediction at Harrow and support the need to include day-specific biomass burning emissions in AURAMS.

\section{Discussion}

\subsection{Comparison to Other receptor modelling studies}

Other receptor-oriented models have been used to estimate POA contributions to $\mathrm{PM}_{2.5}$. Pachon et al. (2010) compared four methods to estimate POA and SOA contributions to long-term filter measurements of $\mathrm{PM}_{2.5}$ : $\mathrm{BC}$ tracer; regression; carbon mass balance (CMB); and PMF. In Atlanta over 

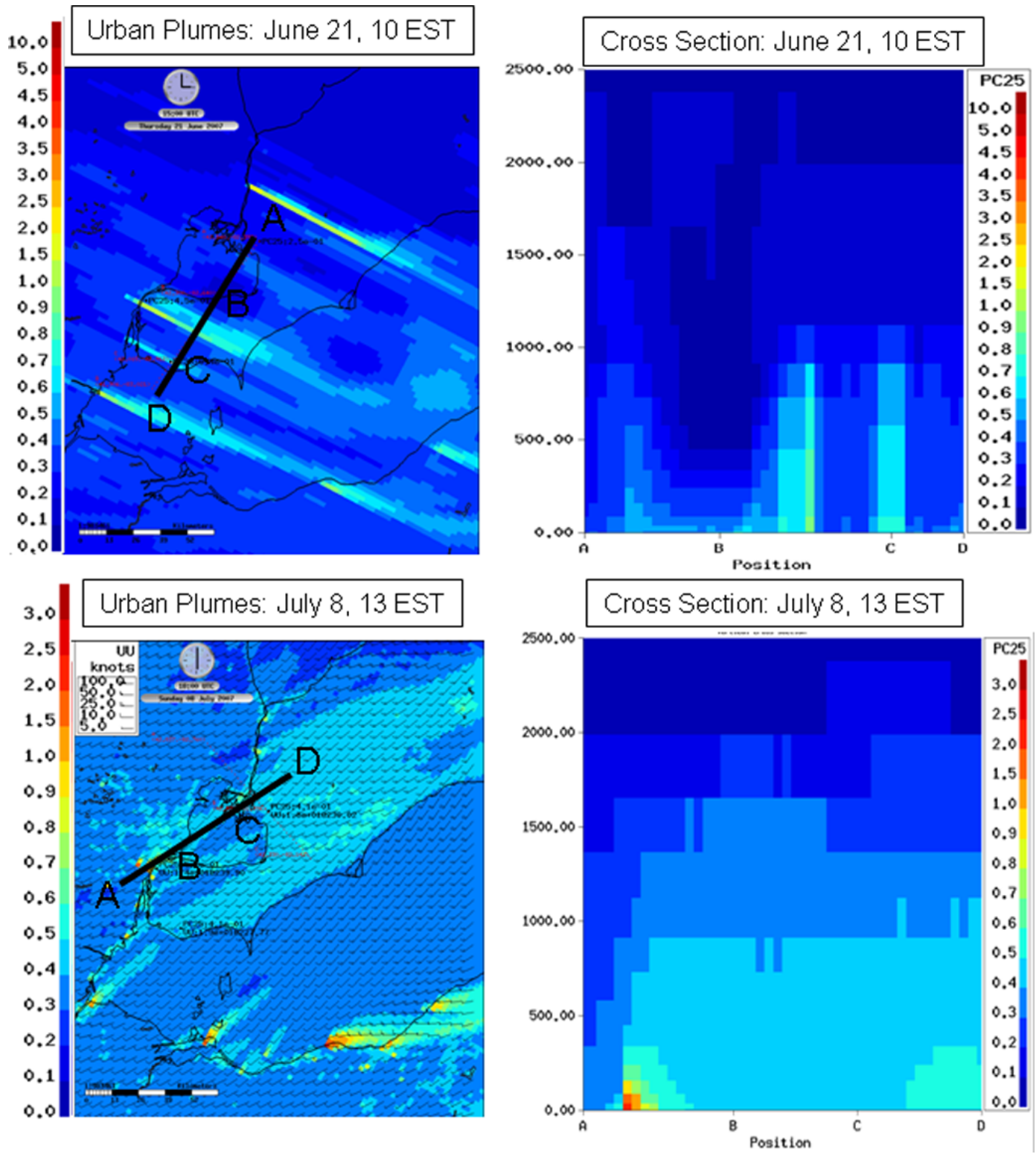

Fig. 7. AURAMS (a) $\mathrm{PM}_{1}$ POA surface distribution for 21 June 2007 at 10:00 EST (upper left) and (b) vertical cross section perpendicular to surface wind direction at Harrow from point $\mathrm{A}$ in northeast to point $\mathrm{D}$ in southwest (upper right), (c) $\mathrm{PM}_{1}$ POA distribution with superimposed surface wind vectors for 8 July 2007 at 13 EST at Bear Creek (lower left) and (d) vertical cross section parallel to surface wind direction from point $A$ in southwest to point $D$ in northeast (lower right).

several years, the CMB method gave the lowest estimate of the relative contribution of POA (54\%) and PMF gave the highest (74\%). Williams et al. (2010) performed hourly measurements of source marker species at Riverside, California during the summer and their PMF analysis showed that primary contributions to OA were $11 \%$ from fuel combustion, $10 \%$ from food cooking, and $7 \%$ from forest fires. Dreyfus et al. (2009) used organic molecular composition measurements for an autumn period in Wilmington, Delaware in a PMF analysis to identify six factors linked to specific sources (diesel exhaust, road dust, meat cooking) or types of compounds (alkanes/alkanoic acids, phthalates, PAHs). For the POA sources, $\sim 1 / 3$ was contributed from fuel combustion (largely diesel) and $\sim 2 / 3$ was from non-combustion sources (dust, meat cooking). Each of these receptor modeling approaches has its advantages, and overall a weightof-evidence assessment using various approaches to source apportionment is favourable.

The most geographically relevant prior receptor-orientated analysis was reported by Zhang et al. (2009). They used monthly measurements of eight individual particle-phase organic marker species as well as $\mathrm{PM}_{2.5} \mathrm{BC}$ and $\mathrm{OA}$ mass 
Table 11. Biomass Burning Influence

\begin{tabular}{|c|c|c|c|c|c|c|c|c|}
\hline Date (EST) & $\begin{array}{l}\text { Model POA } \\
\text { HOA } \\
\text { NMB } \\
\text { RMSE }\end{array}$ & $\mathrm{HOA} / \mathrm{OA}$ & Winds & Meteorology & $\begin{array}{l}\text { Model BC } \\
\text { Meas. BC } \\
\text { NMB } \\
\text { RMSE }\end{array}$ & $\begin{array}{l}\text { Model CO } \\
\text { Meas. CO } \\
\text { NMB } \\
\text { RMSE }\end{array}$ & $\begin{array}{l}\text { Model SO4 } \\
\text { Meas. SO4 } \\
\text { NMB } \\
\text { RMSE }\end{array}$ & $\begin{array}{l}\text { PMF Source } \\
\text { Description }\end{array}$ \\
\hline $\begin{array}{l}\text { Harrow } \\
6 \text { July } \\
\text { 09:00-11:30 }\end{array}$ & $\begin{array}{l}0.20 \pm 0.04 \\
3.6 \pm 0.2 \\
-94 \% \\
3.4 \mu \mathrm{g} \mathrm{m}^{-3}\end{array}$ & $20 \%$ & $\begin{array}{l}\text { SE } \\
\text { light }\end{array}$ & $\begin{array}{l}\text { Well predicted, } \\
\text { switched direction } \\
\text { from N to SE }\end{array}$ & $\begin{array}{l}0.15 \\
0.83 \\
-82 \% \\
0.68 \mu \mathrm{g} \mathrm{m}^{-3}\end{array}$ & $\begin{array}{l}201 \\
296 \\
-32 \% \\
104 \mathrm{ppbv}\end{array}$ & $\begin{array}{l}0.59 \\
1.2 \\
-50 \% \\
0.60 \mu \mathrm{g} \mathrm{m}^{-3}\end{array}$ & $\begin{array}{l}\text { "Biomass } \\
\text { Burning" }\end{array}$ \\
\hline $\begin{array}{l}\text { Harrow } \\
\text { July } 7 \\
\text { 09:00-14:50 }\end{array}$ & $\begin{array}{l}0.48 \pm 0.26 \\
1.7 \pm 0.3 \\
-71 \% \\
1.22 \mu \mathrm{g} \mathrm{m}^{-3}\end{array}$ & $16 \%$ & $\begin{array}{l}\text { WSW } \\
\text { moderate }\end{array}$ & $\begin{array}{l}\text { Well predicted, back } \\
\text { trajectories originate } \\
\text { from NW } \\
\text { (Northern Michigan) }\end{array}$ & $\begin{array}{l}0.12 \\
0.82 \\
-86 \% \\
0.70 \mu \mathrm{g} \mathrm{m}^{-3}\end{array}$ & $\begin{array}{l}205 \\
182 \\
13 \% \\
69 \mathrm{ppbv}\end{array}$ & $\begin{array}{l}5.4 \\
1.1 \\
403 \% \\
5.8 \mu \mathrm{g} \mathrm{m}^{-3}\end{array}$ & "Biomass Burning" \\
\hline
\end{tabular}

over a one-year period in Detroit with PMF analysis to estimate the POA component. Three factors were derived, representing (1) urban primary sources (food cooking, road dust), (2) ORM sources, and (3) other combustion sources (coal). These three POA sources accounted for $57 \%$ of OA mass. In Detroit, in the summer, POA concentration from ORM combustion was estimated at $0.6 \mu \mathrm{g} \mathrm{m}^{-3}$ (60\% of POA). This receptor-based ORM contribution is much larger than the emissions inventory and processing for the Detroit grid cell presented in Sect. 3.2 (28\% ORM). Furthermore, our results for POA bias as a function of HOA mass loading and as a function of $\mathrm{BC} / \mathrm{POA}$ ratio point to an under-prediction in mobile emissions, especially diesel. This is also consistent with the Ying et al. (2007) study, which concluded that BC and POA levels were underpredicted in Los Angeles due to low diesel emissions in the California emissions inventory.

In the Zhang et al. (2009) study, at a rural midwestern US site (Bondville, Illinois), on the other hand, the ORM-sourcedominated factor was negligible compared to the other urban primary sources (food cooking, road dust) and other combustion sources (coal). Their results are similar to the emissions inventory percentages for Indiana presented in Sect. 3.1.

\subsection{Recommendations for future work}

Overall, the methodology of using only four PM chemical speciation profiles (for ORM, ORAA, minor point and major point sources) employed in this study to speciate primary PM emissions resulted in reasonable model performance. The general trend was for model underprediction at higher measured HOA, model overestimation at lower measured HOA, and less biased model results at mean HOA. However, in the future, modelling specific source plumes for source apportionment studies will require further development and use of source-specific (SCC-based) PM chemical speciation profiles (e.g., POA fractions from coal-combustion vs. naturalgas-combustion plumes, separation of diesel from gasoline combustion).

It would be beneficial to design future studies so that additional chemical mass balance analysis could be performed on source-specific marker species. This would complement the PMF analysis done here. Furthermore, it would be enlighten- ing to perform "tagged" source simulations to compare with the interpretations from a CMB analysis. Together these future studies would help to better characterize the bias for our case-study periods.

The magnitude of the area POA sources in the US and Canadian emissions inventories suggests that more effort should be dedicated to reducing uncertainties in these sources (food cooking, road and soil dust). Work should also be done in parallel to continue to develop both improved and new Canadian spatial and temporal profiles at finer resolutions (e.g., add more road-type spatial surrogates, improve meat-cooking surrogates for commercial and residential sectors). The combination of (1) higher urban-scale POA and $\mathrm{BC}$ emissions from diesel combustion, (2) more structured (i.e., less smooth) spatial allocation of area POA emissions in urban areas (food cooking, road dust), and (3) dynamic POA evaporation based on volatility would help the model trends in terms of magnitude and bias from urban to rural scales. In addition, work should continue with adding day-specific biomass-burning emissions capabilities.

\section{Conclusions}

An analysis of the POA emissions inventory for summer conditions in Ontario highlights the diversity of POA sources, with surprisingly large contributions from ORAA sources such as food cooking, tractor fuel combustion, and road and soil dust in addition to the well recognized ORM fuel combustion sources. An analysis of the $\mathrm{PM}_{1}$ POA emissions for the Detroit/Windsor grid cell $\left(42 \times 42 \mathrm{~km}^{2}\right)$ showed contributions of $47 \%$ from ORAA sources, $38 \%$ from point sources, and $15 \%$ from ORM sources. A prior molecularmarker-based PMF analysis of organic aerosol by Zhang et al. (2009) for the same area calculated considerably more ORM contribution for Detroit (60\%). This provided our first evidence that our model ORM emissions may be underestimated for the Detroit/Windsor air shed.

In the study area, many urban and point emissions lie on the shorelines of the Great Lakes and the Detroit River. The influence of mesoscale lake-breeze fronts and circulations on the dispersion of emissions is very complex in this region in 
the summer and creates a challenge and necessity to model POA at high resolution in order to capture the spatial structure of local atmospheric flows. A common flow pattern for southwestern Ontario in the summer is brisk winds from the southwest, which results in longer-range transport of air originating from the U.S Midwest plus superposition of emissions from sources along the shores of Lake Erie. An analysis of the POA emissions inventory was performed for Indiana, a nearby upwind US state for this flow direction, which showed POA emissions to be dominated by ORAA source $(67 \%)$ and point sources $(26 \%)$ and a very small contribution from ORM sources (7\%). These percentages are similar to the published estimates by Zhang et al. (2009) for one rural site in the mid-western US (Bondville, Illinois).

Particle component-based factor analysis was applied to AMS measurements made during the 2007 BAQS-Met field study at one urban site (Windsor, $\mathrm{ON}$ ) and two rural sites (Harrow and Bear Creek, ON) to derive HOA factors. Colocated $\mathrm{CO}, \mathrm{PM}_{2.5} \mathrm{BC}$, and $\mathrm{PM}_{1} \mathrm{SO}_{4}$ measurements were also used to evaluate and interpret AURAMS CTM results along with surface meteorological mesoscale analyses and high-resolution back trajectories. In Windsor, the nighttime model $\mathrm{PM}_{1}$ POA mean was considerably higher than the $\mathrm{PM}_{1}$ HOA mean, with the largest $\mathrm{PM}_{1}$ POA overpredictions occurring in stable model surface layers on calm nights that resulted in the accumulation of urban POA emissions in the lowest model grid layer. For Windsor, the model underpredicted $\mathrm{PM}_{1}$ POA levels at higher BC-to-HOA ratios. This trend provides a second piece of evidence that on-road diesel emissions, which are rich in BC relative to POA, may be under-represented in the model emissions. Additional evidence for this was shown by examining model predictions for air masses originating from southern Detroit, which is a heavily industrialized area with extensive use of diesel trucks. Southern Windsor also includes the major highway for diesel trucks travelling to/from one of the busiest Canada/US border crossings. Work is underway to build new ORM spatial surrogate fields for Canada based on an updated version of the Canadian road network with more road classes.

Scatter plots for Windsor also showed a trend of increasing model $\mathrm{PM}_{1}$ POA overprediction at lower HOA concentrations and at lower BC-to-HOA ratios. This could result from inaccuracies in the spatial surrogate fields used to allocate area-source emissions in space, with under-weighting over urban centers, or from the inability of a model with relatively coarse grid spacing to resolve the spatial distribution of emissions at urban scales. The trend of overprediction at lower HOA mass concentrations is also consistent with the need to include the POA evaporation process as proposed by Robinson et al. (2010).

At the rural Bear Creek supersite, $\mathrm{PM}_{1}$ POA underprediction was also observed for cases of outflow from the DetroitWindsor urban area, whereas there was good agreement in general at Bear Creek for periods when clean background air flowed into the study region from the north. Measurement- derived HOA was also considerably lower at Bear Creek than at Windsor or Harrow.

Campaign-mean POA statistics were considerably worse at the rural Harrow supersite than at either Windsor or Bear Creek. At Harrow, the case studies that were found to contribute to the campaign-mean POA underprediction were: (1) outflow periods from Detroit-Windsor, (2) transboundary flow periods from the US Midwest, and (3) biomass-burning periods. Meteorological influences associated with the frequent lake-breeze conditions likely also contributed to uncertainties at Harrow, which is situated close to the northwest shore of Lake Erie.

The good $\mathrm{PM}_{1} \mathrm{POA}$ agreement at Windsor and $\mathrm{PM}_{1}$ POA underprediction at Harrow vs. the $\mathrm{CO}$ overprediction at Windsor and good $\mathrm{CO}$ agreement at Harrow appears to be in conflict and is not easy to reconcile. One possible explanation could be an underestimate in the ORAA POA emissions for urban areas (possibly related to less structured spatial surrogate fields used for spatial disaggregation of food cooking and dust emissions in urban locations) and an underrepresentation of urban-scale vertical mixing in the lowest model layers, especially at night. In addition, the consistent underprediction of $\mathrm{PM}_{2.5} \mathrm{BC}$ at all sites needs to be considered. Underestimates of vehicle emissions is very likely the cause of the $\mathrm{BC}$ underpredictions.

In summary, this study contributes to the scientific literature on model evaluation and source attribution by:

- Developing a unique model POA evaluation methodology using the positive matrix factorization analysis from the continuous AMS data. The study is multicomponent in nature and focuses on the evaluation of three carbonaceous species simultaneously. Model biases are evaluated in terms of meteorological variables and indicator ratios of air mass source type. Model biases for fresh urban, aged urban and biomass burning case study periods are also calculated and analyzed.

- Results suggest predictions of all three carbonaceous species can be improved by a combination of: (1) increased vertical mixing at urban scales, (2) more structured spatial allocation of area PM emissions (e.g. meat cooking, dust) on urban scales, (3) improved spatial allocation of on-road mobile emissions with more allocation on urban streets and less on rural roads, and (4) a systematic underestimate in the black carbon emission factor from the mobile emission sector.

- Emission inventory analysis for Detroit/Windsor grid cell suggests under-weighting of mobile emission contribution compared to other molecular-marker based receptor modelling studies in the same air shed (Zhang et al., 2009). Large inventory sources for meat cooking POA were identified and suggest more effort should be placed at allocating this source in urban areas. 
- Biomass burning can be an important intermittent source. This study identifies several case study periods during BAQS-Met from PMF and identifies the degree of POA under-prediction.
Supplementary material related to this article is available online at: http://www.atmos-chem-phys.net/12/ 8297/2012/acp-12-8297-2012-supplement.pdf.

\section{Appendix A}

\section{List of acronyms}

$\begin{array}{ll}\text { a.g.l. } & \text { above ground level } \\ \text { AMS } & \text { aerosol mass spectrometer } \\ \text { AQ } & \text { air quality } \\ \text { ATOFMS } & \text { Aerosol time of flight mass spectrometer } \\ \text { AURAMS } & \begin{array}{l}\text { A Unified Regional Air-quality Modelling } \\ \text { System }\end{array} \\ \text { BAQS-Met } & \text { Border Air Quality and Meteorology Study } \\ \text { BBOA } & \text { biomass burning OA } \\ \text { BC } & \text { black carbon (synonymous with elemental } \\ & \text { carbon) } \\ \text { CLBC } & \text { chemical lateral boundary condition } \\ \text { CM } & \text { crustal material } \\ \text { CMB } & \text { carbon mass balance } \\ \text { CO } & \text { arbon monoxide } \\ \text { CRUISER } & \text { Canadian Regional and Urban Investiga- } \\ & \text { tion System for Environmental Research } \\ \text { CS } & \text { case study } \\ \text { CTM } & \text { chemical transport model } \\ \text { EPA } & \text { Environmental Protection Agency } \\ \text { EST } & \text { Eastern Standard Time } \\ \text { GEM } & \text { Global Multiscale Model (Canada's mete- } \\ \text { orology model) } \\ \text { HOA } & \text { hydrocarbon-like OA } \\ \text { IVOC } & \text { intermediate volatile organic compound } \\ \text { LIDAR } & \text { Light Detection and Ranging } \\ \text { MAAP } & \text { multi-angle absorption photometer } \\ \text { NEI } & \text { national emissions inventory } \\ \text { normalized mean bias } \\ \text { NOB }\end{array}$

Acknowledgements. The authors are grateful to Robert McLaren for his contributions in organizing the BAQS-Met field program. The authors acknowledge the work of the EC Pollutant Inventories and Reporting Division in assembling the 2006 Canadian national emissions inventory and the US EPA for providing the 2005 US national emissions inventory. The authors are indebted to EC's Recherche en Prévision Numerique section for the development of the Canadian weather forecast model GEM that was used in this study to drive the AURAMS CTM. The authors are also appreciative of the Air Quality Modelling Applications section at EC's Meteorological Service of Canada for their help and expertise in running SMOKE and in the development of several Tcl data analysis scripts. The authors would also like to acknowledge Andrew Teakles for his contribution in writing scripts for the high-resolution back trajectory analysis.

Edited by: J. W. Bottenheim

\section{References}

Aiken, A. C., de Foy, B., Wiedinmyer, C., DeCarlo, P. F., Ulbrich, I. M., Wehrli, M. N., Szidat, S., Prevot, A. S. H., Noda, J., Wacker, L., Volkamer, R., Fortner, E., Wang, J., Laskin, A., Shutthanandan, V., Zheng, J., Zhang, R., Paredes-Miranda, G., Arnott, W. P., Molina, L. T., Sosa, G., Querol, X., and Jimenez, J. L.: Mexico city aerosol analysis during MILAGRO using high resolution aerosol mass spectrometry at the urban supersite (T0) Part 2: Analysis of the biomass burning contribution and the non-fossil carbon fraction, Atmos. Chem. Phys., 10, 5315-5341, doi:10.5194/acp-10-5315-2010, 2010.

Andreae, M. O. and Gelencsér, A.: Black carbon or brown carbon? The nature of light-absorbing carbonaceous aerosols, Atmos. Chem. Phys., 6, 3131-3148, doi:10.5194/acp-6-3131-2006, 2006.

Bhave, P. V., Pouliot, G. A., and Zheng, M.: Diagnostic model evaluation for carbonaceous $\mathrm{PM}_{2.5}$ using organic markers measured in the southeastern US Environ. Sci. Technol., 41, 1577-1583, 2007.

Boström, C.-E., Gerde, P., Hanberg, A., Jernström, B., Johansson, C., Kyrklund, T., Rannug, A., Törnqvist, M., Victorin, K., and Westerholm, R.: Cancer risk assessment, indicators, and guidelines for polycyclic aromatic hydrocarbons in the ambient air, Environ. Health Perspect., 110, 451-488, 2002.

Brook, J., Makar, P., Sills, D., Hayden, K., and McLaren, R.: The Border Air Quality and Meteorology Study: Exploring the nature of air quality over southern Ontario, in preparation, 2012.

CEP (Carolina Environmental Program): Sparse Matrix Operator Kernel Emissions (SMOKE) processing system, http:// www.smoke-model.org/index.cfm, University of North Carolina, Chapel Hill, 2011. 
Chan, T. W., Huang, L., Leaitch, W. R., Sharma, S., Brook, J. R., Slowik, J. G., Abbatt, J. P. D., Brickell, P. C., Liggio, J., Li, S.M., and Moosmüller, H.: Observations of OM/OC and specific attenuation coefficients (SAC) in ambient fine PM at a rural site in central Ontario, Canada, Atmos. Chem. Phys., 10, 2393-2411, doi:10.5194/acp-10-2393-2010, 2010.

Chen, J., Griffin, R. J., Grini, A., and Tulet, P.: Modeling secondary organic aerosol formation through cloud processing of organic compounds, Atmos. Chem. Phys., 7, 5343-5355, doi:10.5194/acp-7-5343-2007, 2007.

Côté, J., Gravel, S., Méthot, A., Patoine, A., Roch, M., and Staniforth, A.: The operational CMC-MRB global environmental multiscale (GEM) model. Part I: Design considerations and formulation, Mon. Weather Rev., 126, 1373-1395, 1998.

De Gouw, J. A., Middlebrook, A. M., Warneke, C., Ahmadov, R., Atlas, E. L., Bahreini, R., Blake, D.R., Brock, C.A., Brioude, J., Fahey, D.W., Fehsenfeld, F.C., Holloway, J.S., Le Henaff, M., Lueb, R.A., McKeen, S.A., Meagher, J.F., Murphy, D.M., Paris, C., Parrish, D.D., Perring, A.E., Pollack, I.B., Ravishankara, A.R., Robinson, A.L., Ryerson, T.B., Schwarz, J.P., Spackman, J.R., Srinivasan, A., and Watts, L.A.: Organic aerosol formation downwind from the Deepwater Horizon oil spill, Science, 331, 1295-1299, 2011.

Dreyfus, M. A., Adou, K., Zucker, S. M., and Johnston, M. V.: Organic aerosol source apportionment from highly timeresolved molecular composition measurements, Atmos. Environ., 43, 2901-2910, 2009.

Eldering, A. and Cass, G. R.: Source-oriented model for air pollutant effects on visibility, J. Geophys. Res.-Atmos., 101, 1934319369, 1996.

Environment Canada and Health Canada: Canadian Smog Science Assessment, available from first author upon request, 2011.

Environment Canada: AQSC-10-018 Provision of Atmospheric and Emission Modelling Services for Input into Human Health Assessments: Final report on Environment Canada's achievements under ILA 2007-02 (4500194215) related to biodiesel atmospheric modelling. Unpublished report, Air Quality Modelling Applications Sections, Meteorological Service of Canada, 97 pp., available upon request, 2011.

Gong, S. L., Barrie, L. A., Blanchet, J.-P., von Salzen, K., Lohmann, U., Lesins, G., Spacek, L., Zhang, L. M., Girard, E., Lin, H., Leaitch, R., Leighton, H., Chylek, P., and Huang, P.: Canadian aerosol module: A size-segregated simulation of atmospheric aerosol processes for climate and air quality models 1 . module development, J. Geophys Res.-Atmos., 108, AAC 3-1 AAC 316, 2003.

Gong, W., Dastoor, A. P., Bouchet, V. S., Gong, S., Makar, P. A., Moran, M. D., Pabla, B., Ménard, S., Crevier, L.-P., Cousineau, S., and Venkatesh, S.: Cloud processing of gases and aerosols in a regional air quality model (AURAMS), Atmos. Res., 82, 248275, 2006

Grell, G., Freitas, S. R., Stuefer, M., and Fast, J.: Inclusion of biomass burning in WRF-Chem: impact of wildfires on weather forecasts, Atmos. Chem. Phys., 11, 5289-5303, doi:10.5194/acp11-5289-2011, 2011.

Hu, D., Bian, Q., Lau, A. K. H., and Yu, J. Z.: Source apportioning of primary and secondary organic carbon in summer PM2.5 in Hong Kong using positive matrix factorization of secondary and primary organic tracer data, J. Geophys. Res.-Atmos., 115,
D16204, doi:10.1029/2009JD012498, 2010.

IPCC AR4 WG1: Climate Change 2007: The Physical Science Basis, Contribution of Working Group I to the Fourth Assessment Report of the Intergovernmental Panel on Climate Change, edited by: Solomon, S., Qin, D., Manning, M., Chen, Z., Marquis, M., Averyt, K. B., Tignor, M., and Miller, H. L., Cambridge University Press, ISBN, 978-0-521-88009-1, 2007.

Kelly, J., Makar, P. A., and Plummer, D. A.: Projections of mid-century summer air-quality for North America: effects of changes in climate and precursor emissions, Atmos. Chem. Phys., 12, 5367-5390, doi:10.5194/acp-12-5367-2012, 2012.

Lane, T. E., Pinder, R. W., Shrivastava, M., Robinson, A. L., and Pandis, S. N.: Source contributions to primary organic aerosol: Comparison of the results of a source-resolved model and the chemical mass balance approach, Atmos. Environ., 41, 37583776, 2007.

Lanz, V. A., Alfarra, M. R., Baltensperger, U., Buchmann, B., Hueglin, C., and Prévôt, A. S. H.: Source apportionment of submicron organic aerosols at an urban site by factor analytical modelling of aerosol mass spectra, Atmos. Chem. Phys., 7, 15031522, doi:10.5194/acp-7-1503-2007, 2007.

Lee, Y., Cho, G., Dong, S. L., Jee, Y. L., Yoon, K. K., Dong, W. K., and Choi, S.: Influence of the large grid size used in a multimedia mass balance model (POPsME) on the exposure assessment of polychlorinated dibenzo-p-dioxins and dibenzofurans, Environ. Sci. Technol., 41, 5231-5236, 2007.

Levy, I., Makar, P. A., Sills, D., Zhang, J., Hayden, K. L., Mihele, C., Narayan, J., Moran, M. D., Sjostedt, S., and Brook, J.: Unraveling the complex local-scale flows influencing ozone patterns in the southern Great Lakes of North America, Atmos. Chem. Phys., 10, 10895-10915, doi:10.5194/acp-10-10895-2010, 2010.

Li, S.-M., Liggio, J., Graham, L., Lu, G., Brook, J., Stroud, C., Zhang, J., Makar, P., and Moran, M. D.: Condensational uptake of semivolatile organic compounds in gasoline engine exhaust onto pre-existing inorganic particles, Atmos. Chem. Phys., 11, 10157-10171, doi:10.5194/acp-11-10157-2011, 2011.

Liggio, J., Li, S.-M., and McLaren, R.: Reactive uptake of glyoxal by particulate matter, J. Geophys. Res.-Atmos., 110, 1-13, 2005.

Liggio, J., Gordon, M., Brook, J. R., Smallwood, G., Li, S. M., Stroud, C. A., Staebler, R., Lu, G., Lee, P., and Taylor, B.: Emissions of black carbon from gasoline vehicles is underestimated: Insights from near and on-road measurements, Environ. Sci. Technol., 46, 4819-4828, 2012.

Lohmann, R. and Jones, K. C.: Dioxins and furans in air and deposition: A review of levels, behaviour and processes, Sci. Total Environ., 219, 53-81, 1998.

Makar, P. A., Gravel, S., Chirkov, V., Strawbridge, K. B., Froude, F., Arnold, J., and Brook, J.: Heat flux, urban properties, and regional weather, Atmos. Environ., 40, 2750-2766, 2006.

Makar, P. A., Zhang, J., Gong, W., Stroud, C., Sills, D., Hayden, K. L., Brook, J., Levy, I., Mihele, C., Moran, M. D., Tarasick, D. W., He, H., and Plummer, D.: Mass tracking for chemical analysis: the causes of ozone formation in southern Ontario during BAQS-Met 2007, Atmos. Chem. Phys., 10, 11151-11173, doi:10.5194/acp-10-11151-2010, 2010a.

Makar, P. A., Gong, W., Mooney, C., Zhang, J., Davignon, D., Samaali, M., Moran, M. D., He, H., Tarasick, D. W., Sills, D., and Chen, J.: Dynamic adjustment of climatological ozone boundary conditions for air-quality forecasts, Atmos. Chem. Phys., 10, 
8997-9015, doi:10.5194/acp-10-8997-2010, 2010 b.

Mauderly, J. L. and Chow, J. C.: Health effects of organic aerosols, Inhal. Toxicol., 20, 257-288, 2008.

McGuire, M. L., Jeong, C.-H., Slowik, J. G., Chang, R. Y.-W., Corbin, J. C., Lu, G., Mihele, C., Rehbein, P. J. G., Sills, D. M. L., Abbatt, J. P. D., Brook, J. R., and Evans, G. J.: Elucidating determinants of aerosol composition through particle-typebased receptor modeling, Atmos. Chem. Phys., 11, 8133-8155, doi:10.5194/acp-11-8133-2011, 2011.

Mohr, C., Huffman, J. A., Cubison, M. J., Aiken, A. C., Docherty, K. S., Kimmel, J. R., Ulbrich, I. M., Hannigan, M., and Jimenez, J. L.: Characterization of primary organic aerosol emissions from meat cooking, trash burning, and motor vehicles with highresolution aerosol mass spectrometry and comparison with ambient and chamber observations, Environ. Sci. Technol., 43, 24432449, 2009.

Pachon, J. E., Balachandran, S., Hu, Y., Weber, R. J., Mulholland, J. A., and Russell, A. G.: Comparison of SOC estimates and uncertainties from aerosol chemical composition and gas phase data in Atlanta, Atmos. Environ., 44, 3907-3914, 2010.

Pankow, J. F.: An absorption model of gas/particle partitioning of organic compounds in the atmosphere. Atmos. Environ., 28, 185-188, 1994.

Pope III, C. A. and Dockery, D. W.: Health effects of fine particulate air pollution: Lines that connect, JAPCA J. Air Waste Ma., 56, 709-742, 2006.

Robinson, A. L., Donahue, N. M., Shrivastava, M. K., Weitkamp, E. A., Sage, A. M., Grieshop, A. P., and Pandis, S. N.: Rethinking organic aerosols: Semivolatile emissions and photochemical aging, Science, 315, 1259-1262, 2007.

Robinson, A. L., Grieshop, A. P., Donahue, N. M., and Hunt, S. W.: Updating the conceptual model for fine particle mass emissions from combustion systems, JAPCA J. Air Waste Ma., 60, 12041222, 2010.

Sage, A. M., Weitkamp, E. A., Robinson, A. L., and Donahue, N. M.: Evolving mass spectra of the oxidized component of organic aerosol: results from aerosol mass spectrometer analyses of aged diesel emissions, Atmos. Chem. Phys., 8, 1139-1152, doi:10.5194/acp-8-1139-2008, 2008.

Samaali, M., Bouchet, V. S., Moran, M. D., and Sassi, M.: Application of a tagged-species method to source apportionment of primary $\mathrm{PM}_{2.5}$ components in a regional air quality model, Atmos. Environ., 45, 3835-3847, doi:10.1016/j.atmosenv.2011.04.007, 2011.

Schauer, J. J., Kleeman, M. J., Cass, G. R., and Simoneit, B. R. T.: Measurement of emissions from air pollution sources. 2. C1 through C30 organic compounds from medium duty diesel trucks, Environ. Sci. Technol., 33, 1578-1587, 1999.

Sills, D. M. L., Brook, J. R., Levy, I., Makar, P. A., Zhang, J., and Taylor, P. A.: Lake breezes in the southern Great Lakes region and their influence during BAQS-Met 2007, Atmos. Chem. Phys., 11, 7955-7973, doi:10.5194/acp-11-7955-2011, 2011.

Slowik, J. G., Stroud, C., Bottenheim, J. W., Brickell, P. C., Chang, R. Y.-W., Liggio, J., Makar, P. A., Martin, R. V., Moran, M. D., Shantz, N. C., Sjostedt, S. J., van Donkelaar, A., Vlasenko, A., Wiebe, H. A., Xia, A. G., Zhang, J., Leaitch, W. R., and Abbatt, J. P. D.: Characterization of a large biogenic secondary organic aerosol event from eastern Canadian forests, Atmos. Chem. Phys., 10, 2825-2845, doi:10.5194/acp-10-2825-2010, 2010.
Slowik, J. G., Brook, J., Chang, R. Y.-W., Evans, G. J., Hayden, K., Jeong, C.-H., Li, S.-M., Liggio, J., Liu, P. S. K., McGuire, M., Mihele, C., Sjostedt, S., Vlasenko, A., and Abbatt, J. P. D.: Photochemical processing of organic aerosol at nearby continental sites: contrast between urban plumes and regional aerosol, Atmos. Chem. Phys., 11, 2991-3006, doi:10.5194/acp-11-29912011, 2011.

Strawbridge, K. B.: Scanning lidar: A means of characterizing the Noranda-Horne smelter plume, Geochemistry: Exploration, Environment, Analysis, 6, 121-129, 2006.

Stroud, C. A., Morneau, G., Makar, P. A., Moran, M. D., Gong, W., Pabla, B., Zhang, J., Bouchet, V. S., Fox, D., Venkatesh, S., Wang, D., and Dann, T.: OH-reactivity of volatile organic compounds at urban and rural sites across Canada: Evaluation of air quality model predictions using speciated VOC measurements, Atmos. Environ., 42, 7746-7756, 2008.

Stroud, C. A., Makar, P. A., Moran, M. D., Gong, W., Gong, S., Zhang, J., Hayden, K., Mihele, C., Brook, J. R., Abbatt, J. P. D., and Slowik, J. G.: Impact of model grid spacing on regionaland urban- scale air quality predictions of organic aerosol, Atmos. Chem. Phys., 11, 3107-3118, doi:10.5194/acp-11-31072011, 2011.

Takegawa, N., Miyakawa, T., Kondo, Y., Jimenez, J. L., Zhang, Q., Worsnop, D. R., and Fukuda, M.: Seasonal and diurnal variations of submicron organic aerosol in Tokyo observed using the Aerodyne aerosol mass spectrometer, J. Geophys. Res.-Atmos., 111, D11206, doi:10.1029/2005JD006515, 2006.

US EPA SPECIATE program: available at: http://www.epa.gov/ttn/ chief/emch/speciation, 2011.

Williams, B. J., Goldstein, A. H., Kreisberg, N. M., Hering, S. V., Worsnop, D. R., Ulbrich, I. M., Docherty, K. S., and Jimenez, J. L.: Major components of atmospheric organic aerosol in southern California as determined by hourly measurements of source marker compounds, Atmos. Chem. Phys., 10, 11577-11603, doi:10.5194/acp-10-11577-2010, 2010.

Ying, Q., Fraser, M. P., Griffin, R. J., Chen, J., and Kleeman, M. J.: Verification of a source-oriented externally mixed air quality model during a severe photochemical smog episode, Atmos. Environ., 41, 1521-1538, 2007.

Zhang, J., Gong, W., Leaitch, W. R., and Strapp, J. W.: Evaluation of modeled cloud properties against aircraft observations for air quality applications, J. Geophys. Res.-Atmos., 112, D10S16, doi:10.1029/2006JD007596, 2007.

Zhang, H. and Ying, Q.: Source apportionment of airborne particulate matter in southeast Texas using a source-oriented 3D air quality model, Atmos. Environ., 44, 3547-3557, 2010.

Zhang, Q., Rami Alfarra, M., Worsnop, D. R., Allan, J. D., Coe, H., Canagaratna, M. R., and Jimenez, J. L.: Deconvolution and quantification of hydrocarbon-like and oxygenated organic aerosols based on aerosol mass spectrometry, Environ. Sci. Technol., 39, 4938-4952, 2005.

Zhang, Q., Jimenez, J. L., Canagaratna, M. R., Allan, J. D., Coe, H., Ulbrich, I., Alfarra, M. R., Takami, A., Middlebrook, A. M., Sun, Y. L., Dzepina, K., Dunlea, E., Docherty, K., DeCarlo, P. F., Salcedo, D., Onasch, T., Jayne, J. T., Miyoshi, T., Shimono, A., Hatakeyama, S., Takegawa, N., Kondo, Y., Schneider, J., Drewnick, F., Borrmann, S., Weimer, S., Demerjian, K., Williams, P., Bower, K., Bahreini, R., Cottrell, L., Griffin, R. J., Rautiainen, J., Sun, J. Y., Zhang, Y. M., and 
Worsnop, D. R.: Ubiquity and dominance of oxygenated species in organic aerosols in anthropogenically-influenced Northern Hemisphere midlatitudes, Geophys. Res. Lett., 34, L13801, doi:10.1029/2007GL029979, 2007.

Zhang, Y.: Online-coupled meteorology and chemistry models: history, current status, and outlook, Atmos. Chem. Phys., 8, 28952932, doi:10.5194/acp-8-2895-2008, 2008.
Zhang, Y., Sheesley, R. J., Schauer, J. J., Lewandowski, M., Jaoui, M., Offenberg, J. H., Kleindienst, T. E., and Edney, E. O.: Source apportionment of primary and secondary organic aerosols using positive matrix factorization (PMF) of molecular markers, Atmos. Environ., 43, 5567-5574, 2009.

Zhang, J., Moran, M., Makar, P., Sassi, M., and Zheng, Q.: Investigation of cross-border differences in the spatial distribution of onroad mobile emissions between the US and Canada. Poster 13, 19th International Emission Inventory Conference, Sept. 27-30, San Antonio, Texas, 2010. 